\title{
YOU HAD ME AT HELLO: EXAMINING THE IMPACT OF POWERFUL INTRODUCTORY EMOTIONAL HOOKS SET FORTH IN APPELLATE BRIEFS FILED IN RECENT HOTLY CONTESTED U.S. SUPREME COURT DECISIONS
}

\begin{abstract}
MAUREEN JOHNSON ${ }^{*}$
"You had me at "hello." We may not have all seen the movie, but we likely have used the phrase. ${ }^{1}$ A decision is made in an instant-a gut reaction based on some kind of an emotional trigger. Even if the decision later is questioned, the analysis is skewed. Pathos over logos. Once our heart truly has made up its mind, there always is a way to convince our brain that the decision is correct.

Such rash decision-making obviously has no place at the Supreme Court. Or does it?

This Article posits that powerful emotional hooks set forth in introductory paragraphs in stellar briefs-emotional hooks that often have nothing at all to do with the merits of the case-do certainly play a role in the determination of hotly contested Supreme Court decisions. As a practical matter, there often are two ways to frame an issue legitimately. In this circumstance-when both sides could be correct-why is it surprising that pathos might tip the scales?

Of course, we likely never will know what truly swayed a particular justice in any given five-to-four decision, but what we do know is that the "hellos"-the emotional hooks set forth in the introductory paragraphs of briefs-are often showcased front-and-center in the resulting Supreme Court opinion. For this reason alone, a wise appellate practitioner always strives to win both emotionally and intellectually.

The first part of this Article addresses the belief shared by many appellate practitioners that the best briefs do indeed make a compelling case on both an emotional and intellectual level. The origins of this view are timeless, memorialized in the writings of Aristotle and echoed in the writings of admired jurists, such as Benjamin Cardozo and Richard Posner. ${ }^{2}$ Nor can it be disputed that court opinions are routinely written in a manner intended to persuade the
\end{abstract}

* Maureen Johnson is an Associate Clinical Professor at Loyola Law School, Los Angeles. Prior to teaching, the author practiced law at Mayer Brown, LLP and Kaye Scholer, LLP. The author thanks all of her colleagues in the skills department at Loyola Law School, Los Angeles, particularly including Professors Jean Boylan, Robert Brain, and Stephanie Williams and Associate Deans Cindy Archer and Alexandra Natapoff. The author also thanks Washburn University of Law, in particular, Professors Emily Grant and Joseph Mastrosimone, for hosting the Washburn University Junior Legal Writing Scholars Workshop, as well as fellow participants Professor Wendy Hess and Professor Michael Pinsof. Thanks also to University of Nevada at Las Vegas (William S. Boyd School of Law) for hosting the 2015 West Coast Rhetoric Conference, where this paper was presented. Special thanks to all participants, including Professors Terrill Pollman, Teresa Bruce, Lori Johnson, Jeanne Merino, and Nantiya Ruan.

1. The quote is from the ending scene in Jerry McGuire, a 1996 film starring Tom Cruise, Cuba Gooding Jr., and Rene Zellweger. JeRry McGuire (Gracie Films 1996).

2. See generally Benjamin N. Cardozo, The Nature of the Judicial Process (Yale Univ. Press 1949); Richard A. Posner, How Judges Think (Harvard Univ. Press 2008).

http://dx.doi.org/10.18060/4806.0071 
reader of the moral and legal soundness of the decision. As a practical matter, pathos has to come from somewhere. Court clerks do not phone up litigants in an effort to ferret out the emotional facts of a dispute. The pathos set forth in court opinions comes from one very specific source: the briefs.

This section also discusses the science as to exactly why emotional hooks are so powerful. As explained by cognitive scientists, we all have unshakeable deeply ingrained beliefs that go to the core of our existence and how we view the world. ${ }^{3}$ When a story or an image awakens these beliefs, it evokes a predictable emotional response that, once triggered, becomes almost set in stone. Put simply, emotion is so strong that logos-based arguments fall on deaf ears.

Take the recent example of the horrific killings in Charleston, South Carolina. Twenty-one-year-old Dylann Roof opened fire as he sat in a prayer-group meeting at the Emanuel African Methodist Episcopal Church, senselessly killing nine African-Americans, including pastor and State Senator Clementa C. Pinckney. ${ }^{4}$ No doubt, as you read those words many images came to your mind, including the image of Dylann Roof draped in a Confederate flag holding a gun that he later would use to carry out the race-based massacre. ${ }^{5}$ That image is the type that is indelible, forever embedded in our emotional core. Those who previously tolerated the right of individuals to display the Confederate flag proudly could simply no longer do so. Retailers quickly pulled product, and, on July 9, 2015, lawmakers voted to take down the Confederate flag that stood in front of the South Carolina State House for decades. ${ }^{6}$

This section concludes by noting the powerful role that deeply ingrained moral beliefs play in both how we conduct ourselves as Americans and how our

3. See, e.g., George Lakoff, Whose Freedom? The Battle over America's Most IMPORTANT IDEA 12-16 (Picador 2006).

4. Senator Pinckney was mourned by colleagues who described him as a peaceful legislator who was the "moral conscience" of the South Carolina General Assembly. Andrew Shain \& Matt Walsh, Pinckney 'Was the Moral Conscience of the General Assembly,' Charlotte ObSERVER (June 18, 2015), http://www.charlotteobserver.com/news/local/article24841543.html [http://perma. cc/6W8E-UH9V]. For a more thorough description of the events, see Jonathan Weisman, Killings Add Painful Page to Storied History of Charleston Church, N.Y. Times (June 18, 2015), http://www.nytimes.com/2015/06/19/us/charleston-killings-evoke-history-of-violence-againstblack-churches.html?_r=0 [http://perma.cc/W2D6-WRTL].

5. See Francis Robles, Dylan Roof Photos and a Manifesto Are Posted on a Website, N.Y. TIMEs (June 20, 2015), http://www.nytimes.com/2015/06/21/us/dylann-storm-roof-photos-websitecharleston-church-shooting.html [http://perma.cc/5LBN-A8RH].

6. Meghan Keneally, SC Confederate Flag Taken Down from State Capital in South Carolina, ABC News (July 10, 2015, 10:29 AM), http://abcnews.go.com/US/confederate-flagstate-capitol-south-carolina/story?id=32354059 [http://perma.cc/F6M8-C2E8]. Notably, the flag had been raised for the exact purpose of signaling South Carolina's lack of support for the Supreme Court's decision in Brown v. Board of Education. See Maria Stainer, Ken Burns: Confederate Flag Is About 'Resistance to Civil Rights, 'WASH. Times (June 26, 2015), http://www.washingtontimes. com/news/2015/jun/26/ken-burns-confederate-flag-is-about-resistance-to/ [http://perma.cc/858WCGKT]. 
judiciary craft legal opinions. Given that impact, the advice for any practitioner-whether at the trial or appellate court level - is to frame the issues and facts in a manner that not only convinces the judge the law is in your favor, but that also makes the judge want to rule in your favor.

That begs the question: exactly how is this done?

The second part of this Article answers that question by analyzing the briefs and opinions in five recent five-to-four U.S. Supreme Court cases: Obergefell $v$. Hodges (same-sex marriage); ${ }^{7}$ Adoptive Couple v. Baby Girl (parental rights under the Indian Child Welfare Act) $;^{8} A T \& T$ Mobility v. Concepcion (preemption/unconscionability of class-wide arbitration waivers) $;{ }^{9}$ Burwell $v$. Hobby Lobby Stores, Inc. (religious freedom/abortion rights) $;{ }^{10}$ and Glossip v. Gross (death penalty/drug protocol). ${ }^{11}$ The focus is not on the correctness of these Supreme Court decisions, but rather on deconstructing the submitted briefs in order to gain a better understanding as to how the introductory hooks might have factored into the outcome of these cases and /or the content of the Supreme Court opinion.

Each of these cases falls within the category that this author regards as those that could have been decided differently, yet still have been grounded on solid legal precedent. This is the exact circumstance where pathos becomes ever so important. The top scribes penning the prevailing briefs in each of these cases were certainly up for the challenge. Each brief began with an emotional "hello" that would be hammered-home again and again throughout the brief and would make its way into the Supreme Court opinion.

The final part of this Article summarizes the findings for the purpose of providing guidance to practitioners as to how to craft an effective "hello." It is no secret that our judicial system is overly taxed. ${ }^{12}$ Now more than ever, an effective brief writer has to win the reader over both in the heart and in the mind. The writer needs to do that from the get-go.

This part also briefly explores the need to go beyond relying upon stock techniques and to dig deeper by taking the pulse of ever-changing social norms regarding what is fair and just. That is where the power of persuasion lies. Judicial opinions make news for a reason. America has fallen in love with the lore of the "running of the interns" who deliver hard copies of landmark Supreme Court decisions to analysts, microphone in hand, who quickly digest the opinion and announce the ruling on a national platform. ${ }^{13}$ The focus is not on legalese, but rather on the heart and soul of the opinion. Put differently, the focus is on the story. That is why it is so important for a practitioner to provide both a legal and

7. 135 S. Ct. 2584 (2015).

8. 133 S. Ct. 2552 (2013).

9. 563 U.S. 333 (2011).

10. 134 S. Ct. 2751 (2014).

11. 135 S. Ct. 2726 (2015).

12. David Beck, Is Our Judiciary Under Serious Attack? Separation of Powers, 67 TEX. B.J. 974, 979 (2004).

13. See infra note 226 and accompanying text. 
a moral justification in their briefing. It just might matter.

\section{From Aristotle to the 21 st Century and Beyond: Why Pathos Is So IMPORTANT TO THE POWER OF PERSUASION}

An American tourist visiting Athens is almost sure to be reminded that our democratic system is derived from the ancient Greeks. It was on these cobblestone roads that Plato, Socrates, and Aristotle passionately proclaimed the virtues of freedom of speech, freedom of thought, and the need for open public discourse.$^{14}$ One can only imagine ancient Athenians traversing the steps of the Acropolis as they made their case to fellow townsmen as to where the next sewer line should be placed or, more importantly, listening to orators during the Periclean Age respond to the threat of a possible war with neighboring Sparta. ${ }^{15}$ As later would be explained by Aristotle, whether a trivial disagreement or a matter of utmost public importance, every such argument should include one very important component: pathos. ${ }^{16}$

As set forth below, Aristotle got it right. Every argument is evaluated in terms of three key elements: ethos (credibility), logos (logic), and pathos (emotion). ${ }^{17}$ Although certain judges and scholars have argued that emotion has no place in legal reasoning ${ }^{18}$ this simply is not so. Even the dusty casebooks that house the reported opinions from centuries past often set forth the facts in a manner intended to satisfy a reader's sense of moral justice. ${ }^{19}$ There are sound scientific reasons for that. We are "hard-wired" for story. ${ }^{20} \mathrm{We}$ want to know the outcome

14. See Michal D. Murray, The Great Recession and the Rhetorical Canons of Law and Economics, 58 LoY. L. REV. 615, 625 n.20, 654 (2012); see also Robert K. Fleck \& F. Andrew Hanssen, The Origins of Democracy: A Model with Application to Ancient Greece, 49 J.L. \& ECON. 115, 146 (2006).

15. Id.

16. Jamal Greene, Pathetic Argument in Constitutional Law, 113 Colum. L. Rev. 1389, 1398-99 (2013). Greene emphasized the need for all three of these fundamental principles in persuasion. Id. Greene also talked generally about the role of pathos in Supreme Court opinions. See, e.g., id. at 1419-22.

17. Id. at $1398-99$.

18. Id. at 1414 (referring to Justice Scalia and Bryan Garner).

19. See Jeffrey A. Van Detta, The Decline and Fall of the American Judicial Opinion, Part II: Back to the Future from the Roberts Court to Learned Hand-Segmentation, Audience, and the Opportunity of Justice Sotomayor, 13 BARRY L. REV. 29, 79-80 (2009). In addition to studying the jurisprudence of Judge Learned Hand and his struggle to find the right "balance" of empathy and reason, Van Detta discussed the wisdom and empathy of King Solomon. Id. Van Detta made the observation that it is "well-documented that the general public desires empathy as a quality of any lawyer-practitioner or judge." Id. at 80.

20. Kenneth D. Chestek, Competing Stories: A Case Study of the Role of Narrative Reasoning in Judicial Decisions, 9 Legal Comm. \& RHETORIC: JALWD 99, 102 (2012) (citing Kendall Haven, Story Proof: The Science Behind the Startling Power of Story 3-4 (Libraries Unlimited 2007) (noting "numerous studies suggest[] that humans have told stories to 
and we want to know that outcome is fair.

\section{A. Fact: Ethos, Logos \& Pathos Is Everywhere}

"Mommy, mommy," cries out a four-year old. "Layla's mother lets her play on the big-kid slide. Why can't I?" If permission is denied, a torrent of tears ensues, interrupted only by the words: "That's not fair." A future trial lawyer might assert other emotional appeals, such as that he or she is particularly deserving because of prior good behavior-for example, if he or she cleaned up his or her room without being asked. Another child may even scornfully characterize the decision-maker's action as "not nice" or even "mean."

This scenario has undoubtedly played out an infinite amount of times throughout the world. Whether it be for ice cream, extended play-time, or the latest Xbox, children intuitively know to support arguments not only with logic, but also with emotion. Yet these children have never even heard of Aristotle, let alone, ethos, $\log o s$, and pathos. How can this be? The answer is easy. It is not so much that Aristotle came up with a primer for effective argument. Instead, Aristotle made observations as to how effective arguments can and should be made. ${ }^{21}$ He put his very wise finger on exactly what we all naturally do when we want to persuade, specifically including use of pathos. ${ }^{22}$

Aristotle's observations are both timeless and universal. Numerous disciplines have found a common touchstone based upon the need for ethos, logos, and pathos whenever the objective is to persuade. ${ }^{23}$ Books have adopted Aristotle's principles to specific fields, such as politics, marketing, and even entertainment. $^{24}$ Not surprisingly, Aristotle's principles have been applied to law. ${ }^{25}$ Still, despite the fact that lawyers are hired for the exact purpose of advocating for a specific result, some naysayers argue that emotional appeals have no place in legal briefs. ${ }^{26}$ At most, such appeals should be made at oral argument. This harkens back to the days of old when legal briefs were supposed to be just that-brief and supposedly unbiased explanations of the facts and legal authorities to enable a judge to render a reasoned decision. ${ }^{27}$ Of course, this all

each for 100,000 years and that stories are universal throughout all cultures")).

21. See Edward J. Imwinkelried, A Brief Essay on Aristotle, Philosopher-Litigator, 34 Ам. J. TRIAL ADVOC. 135, 140 (2010) (discussing The Art of Rhetoric and noting the applicability of Aristotle's “insights").

22. Id.

23. Id. (noting even Aristotle envisioned multiple platforms for use of rhetoric). Imwinkelried also discussed how modern day trial manuals echo Aristotle's three main principles: ethos, logos and pathos. Id. at 146-147.

24. See, e.g., LAnce Lee, A Poetics for Screenwriters (Univ. of Texas Press 2001).

25. See Imwinkelried, supra note 21, at 139-43 (listing several specific and general uses of Aristotle's principles including developing a "theory of the case").

26. Greene, supra note 16, at 1414.

27. See Helen A. Anderson, Changing Fashions in Advocacy: 100 Years of Brief-Writing Advice, 11 J. ApP. PraC.\& Process 1, 2 (2010). Anderson's article discussed how the modern brief 
but ignores the fact that our judiciary is based upon the adversarial system. ${ }^{28}$ It also ignores that judges are human beings making profound decisions that affect other human beings. ${ }^{29}$

No later than the turn of the twentieth century, many scholars, practitioners, and even judges were soundly recognizing that effective briefs simply had to have both an emotional and intellectual appeal. ${ }^{30}$ In this author's opinion, this likely corresponded with the advent of widespread dissemination of the daily news. Beginning in 1908, movie theaters began running newsreels just prior to the main feature. ${ }^{31}$ Controversial judicial decisions garnered national attention. ${ }^{32}$ Media coverage included not only the facts of a case, but pictures of the litigants as well as their personal stories. ${ }^{33}$ These visual images naturally evoked empathy. The

"evolved over time from a short outline of point-headings" to a more substantive, lengthy, and adversarial document. Id. Anderson noted emotional appeals could previously be saved for oral argument. $I d$. at 3,10 . That changed in the early nineteenth century when "classic legal formalism" gave way to "legal realism." Id. at 3.

28. Robert P. Lawry, Cross-Examining the Truthful Witness: The Ideal Within the Central Moral Tradition of Lawyering, 100 Dick. L. REv. 563, 566 (1996).

29. As Judge Jack Weinstein put, "It seems to me that every person appearing before the judge is a human being and entitled to be treated with dignity, and that often requires that we speak face-to-face and try to . . . appreciate that we have a human being before us." Susan A. Bandes, Empathy and Article III: Judge Weinstein, Cases and Controversies, 64 DePAUL L. ReV. 317, 317 (2015) (quoting Kenneth P. Nolan, Weinstein on the Courts, LiTIG., Spring 1992, at 24, 26); see also Charles A. Reich, A Passion for Justice: Living with and Clerking for Justice Hugo Black, in In ChAmbers 111, 116 (Todd C. Peppers \& Artemus Ward eds., 2012) (noting that "Justice [Hugo] Black was acutely sensitive to the injury done to any individual and the harm done to society in any given case").

30. As early as the 1920s, Professor Karl Lllyweln talked of the "intuitive" nature of judicial decision-making. Anderson, supra note 27, at 3 (citing Arthur C. Bachrach, Reflections on Brief Writing, 27 ILl. L. REV. 374, 377-78 (1932)). A lawyer's role "came to be seen as that of an artist seeking to move judicial hearts, rather than a scientist assisting the court in a search for the law." $I d$. Lawyers originally "apologiz[ed]" for inclusion of emotional appeals. Id. at 12 (citing K.N. Llewellyn, The Modern Approach to Counseling and Advocacy-Especially in Commercial Transactions, 46 COLUM. L. REV. 167, 183 (1946)). Lawyers since began focusing on the chore of "making the facts talk." Id.

31. See Amy Gajda, The Justices and News Judgment: The Supreme Court as News Editor, 2012 BYU L. REv. 1759, 1773-74 (2012) (discussing Supreme Court cases involving whether newsreels were exempt from censorship because they were akin to "newspapers" in that they "used 'photographs [that were] promptly secured a few days after the events which they depict happen[ing]' and therefore 'regularly furnish[ed] and publish[ed] news,' albeit 'through the medium of motion pictures"').

32. See generally Elliot E. Slotnick \& Jennifer A. Segal, Television News and the Supreme Court-All the News That's Fit to Air (Cambridge Univ. Press 1998).

33. It is well-established that mainstream media coverage of Supreme Court decisions must have an emotional appeal. Id. at 27-32. Reporters routinely search for the "human element" to make their story interesting. Id. at 28 . As put by one reporter: "Who are the people and why are they mad 
public wanted to know more than that a Supreme Court opinion was solidly grounded on legal precedent. Quite frankly, most of the public probably did not care about that at all. What the public wanted to know was that the decision was just. $^{34}$

As noted above, judicial realists, such as Justice Cardozo and Judge Posner, frankly admit that a judge cannot simply check their personal bias at the door. ${ }^{35}$ Judges find ways to present facts in a manner that at least somewhat provides a moral justification for their rulings. ${ }^{36}$ Whether for pride, posterity, or simply to be able to look themselves in the mirror, judges make clear both that they knew they were adjudicating matters that truly affected the litigants and that they got it right. ${ }^{37}$

It also seems fairly undisputed that the justices of the Supreme Court care about public perception, more specifically that the public believes that the decisions are both just and the result of unbiased reasoning. ${ }^{38}$ For example, it has

at each other?" Id. Ultimately, it is the "impact" on everyday people that drives interest. Id.

34. See id.

35. CARDOZO, supra note 2, at 12-14, 167; PoSNER, supra note 2, at 110-11. For an excellent discussion of Justice Cardozo's views, see Kim M. Wardlaw, Umpires, Empathy, and Activism: Lessons from Judge Cardozo, 85 Notre DAME L. Rev. 1629 (2010). Certain of Judge Posner's views are nicely detailed in Susan A. Bandes, Empathetic Judging and the Rule of Law, 2009 CARDOZO L. REV. DE NOVO 133, 137 (2009); see also infra note 49 and accompanying text.

36. See generally id.; see also Chris Rideout, Storytelling, Narrative Rationality, and Legal Persuasion, 14 Legal Writing: J. Legal Writing InSt. 53, 77 (2008) (noting that "[f]or Supreme Court decisions, the narratives are stories not only about the case at hand, but also about who we are or wish to be as a community").

37. A recent example might be the decision by Judge Berman in the dispute between Patriot's quarterback Tom Brady and the National Football League ("NFL"). See Nat'l Football Mgmt. Council v. Nat'l Football League Players Ass'n, Nos. 15 Civ. 5916 (RMB) (JCF), 2015 WL 5148739 (S.D.N.Y. 2015), appeal docketed, (2d Cir. Sept. 2, 2015). The media widely covered this dispute over nine months before it came to Judge Berman for a relatively speedy disposition. An arbitration ruling by NFL Commissioner Roger Goodell upheld a four-game suspension based upon a finding that Brady was "generally aware" of purported illegal ball deflation in a conference championship game. Id. All eyes were on Judge Berman and he delivered a twenty page, extremely detailed ruling. $I d$. Media reports quickly picked up on what was described as Judge Berman's "hammer-blow" to Goodell, namely that Judge Berman blasted Goodell for "issuing his own brand of industrial justice." See Eric Edhelm, Why Did Judge Berman Rule in Tom Brady's Favor?, SHutdown CORNER (Sept. 3, 2015, 11:37 AM), http://sports.yahoo.com/blogs/nfl-shutdowncorner/why-did-judge-berman-rule-in-tom-brady's-favor-153746084.html [http://perma.cc/348BBS7H]. Notably, Judge Berman previously told the parties to "tone down their rhetoric." Rachel Axxon, Deflategate Judge Tells NFL, Union to 'Tone Down' Talk, USA TODAY SPORTS (July 30, 2015, 9:23 PM), http://www.usatoday.com/story/sports/nfl/2015/07/30/deflategate-judge-tells-nflunion-tone-down-talk/30901883/ [http://perma.cc/K4Z8-X44H].

38. See Rideout, supra note 36, at 77. Rideout noted that "Supreme Court decisions themselves offer arguments for their own validity - including an implicit argument based on the underlying narratives." Id. Put differently, the Supreme Court "not only offers a legal argument to 
been widely speculated that the unanimous decision in Brown v. Board of Education was carefully orchestrated.$^{39}$ Notably, the case was heard in the spring of 1953 and reheard in the fall at the urging of Justice Felix Frankfurter ${ }^{40}$ It is believed that this was a stalling tactic to give the justices more time to come to a unanimous agreement. ${ }^{41}$ When Chief Justice Earl Warren was appointed, he made that happen. ${ }^{42}$ Warren wrote the short-but unanimous-opinion. ${ }^{43}$ Although Brown was the right decision, there were many in America who thought just the opposite at the time the decision was handed down. ${ }^{44}$ The unanimity of the Brown opinion was expected to quell the anticipated public backlash at least somewhat. ${ }^{45}$

As discussed below, pathos is powerful. Scientific evidence suggests that even if we do not believe we are making decisions based on emotions that might not be the case. ${ }^{46}$ Emotions may well dictate, or at least inform, the manner in which decisions are made. ${ }^{47}$

\section{B. Fact: Emotional Appeals Can Stir Deeply-Ingrained Moral Beliefs and Trigger an Immediate and Predictable Emotional Response That Is Difficult to Set Aside}

The 2004 presidential election pitted John Kerry against incumbent George $\mathrm{W}$. Bush. ${ }^{48}$ This author recalls discussing the election with an acquaintance who had recently retired from a long career in law enforcement. He was a life-long Democrat, but he was not certain how he would vote. Critical to his analysis was the fact that three decades earlier Kerry, a decorated war-veteran, had testified in front of the Senate Foreign Relations Committee regarding his critical views about the United States' involvement in the Vietnam W ar. ${ }^{49}$ Kerry is famously

support its holding[s], but also locates that argument within an implicit narrative framework about what kind of people we are and what kind of world we might inhabit." Id. In so doing, the Supreme Court speaks to a "universal audience." Id.; see also infra notes 87-93 and accompanying text.

39. See James L. Hunt, Brown v. Board of Education After Fifty Years: Context and Synopsis, 52 MerCer L. Rev. 549, 561-68 (2001).

40. Id. at 565 .

41. Id. at 567 .

42. Id. at 568 .

43. Brown v. Bd. of Educ., 349 U.S. 294, 298 (1955).

44. See Hunt, supra note 39, at 561-68.

45. Id.

46. See infra note 55 and sources cited.

47. Id.

48. Michael Kranish et al., John F. Kerry: The Complete Biography by the Boston Globe Reporters Who Knew Him Best 348-86 (Pub. Affairs 2004).

49. Id. at 110-40. Kerry testified on April 22, 1971, as a representative of the Vietnam Veterans Against the War ("VVAW"). He was twenty-seven years old. Id. Kerry's opening statement referenced both his belief that the United States should withdraw from the war, as well as the purported fact that American military had engaged in atrocious war crimes, including rape, 
quoted as saying: "How do you ask a man to be the last man to die in Vietnam? How do you ask a man to be the last man to die for a mistake?" ${ }^{50}$ Kerry also testified about atrocities he believed American soldiers committed. ${ }^{51}$ Although my friend had voted for Democrat presidential candidates all of his life and believed in both the Democratic platform and the specific ideals advanced by Kerry, he just could not get past Kerry's testimony. In my friend's words, "You just don't do that." 52

Although I do not know how my friend ultimately voted, his angst can be logically explained by cognitive science. He had to reconcile two deeply ingrained sets of values, including one that caused him to have a strong visceral reaction. On one hand, he had a firmly entrenched belief in always voting Democrat in presidential elections and there was no logical reason based on Kerry's current political ideology for his not doing so. On the other hand, he had an equally firm belief that no person who openly criticized U.S. military actions should ever be President. Cognitive scientists explain this conundrum as the classic circumstance in which a person is forced to forge new ground. ${ }^{53}$ If my friend was going to cast a vote, he had to find a way to carve exceptions to one or both of his preconceived values that he previously thought were absolute.

As shall be shown, powerful emotional reactions are not easy to dismiss. ${ }^{54}$ Although we may tell ourselves that we can set aside such responses when we make decisions, science tells us that we are not as objective as we think. ${ }^{55}$ Once

dismemberment, and mass murder. Id. Following the hearings, Kerry, along with thousands of other members of the VVAW, demonstrated at the U.S. Capital Building. Id. During that demonstration, Kerry and the other veterans tossed their war medals over a fence in protest. Id.

50. Id. at 123 .

51. Id. at 124 .

52. Social commentators recognized that the Bush campaign "launched an attack" against Kerry based upon his testimony at the 1971 hearings. BERNARD VON BOTHMER, FrAming THE Sixties, The Use and Abuse of a Decade from Ronald Reagan to George W. Bush 209 (Univ. of Mass Press 2010). Others followed suit, including the Swift Boat Veterans for Truth, who also launched an inflammatory national ad campaign condemning Kerry for what they deemed his "false" statements at the hearing. $I d$. at 213 . None of these veterans actually served with Kerry in the war. Id.

53. See Linda L. Berger, The Lady, or the Tiger? A Field Guide to Metaphor and Narrative, 50 WASHBURN L.J. 275 (2011). Berger's article discussed "cognitive frames" and "mental blueprints." Id. at 280 . She told the tale of the "Lady, or the Tiger" to demonstrate the circumstance where we are torn by "conflicting emotions." Id. at 276; see also Anna-Maria Marshall, Injustice Frames, Legality, and the Everyday Construction of Sexual Harassment, 28 L. \& Soc. INQUIRY 659, 673 (2003) (discussing the need to reconcile competing frames in the context of sexual harassment).

54. See infra notes 56-112.

55. See Nicole E. Negowetti, Judicial Decisionmaking, Empathy and the Limits of Perception, 47 AKron L. Rev. 693, 711-12 (2014). When a subject "believe[d] himself to be objective, such belief license[d] him to act on his biases." Id. at 711 (citing Eric Luis Uhlmann \& Geoffrey L. Cohen, "I Think It, Therefore It's True": Effects of Self-Perceived Objectivity on Hiring Discrimination, 104 Organizational Behav. \& Hum. Decision Processes 207, 210-11 
something grabs us emotionally, the proverbial bell has been rung. ${ }^{56} \mathrm{We}$ can tell ourselves to ignore the bell, but we cannot ignore the fact that it was heard. At minimum, we might have an "implicit" or subconscious bias that leaks into our decision-making. ${ }^{57} \mathrm{We}$ are more open to resolving the issue in accordance with our emotional reaction. ${ }^{58} \mathrm{We}$ might also try to rationalize our emotions by resort to logical justification. ${ }^{59}$ Put simply, we talk ourselves into believing what we want to believe. ${ }^{60}$

When you think about it, the manner in which we "think" is lightning fast, at least in terms of our initial perceptions. ${ }^{61}$ Imagine yourself walking down a busy city street. Your brain may have already made some default choices, such as the location of the city as well as the time of day, weather, season, etc. ${ }^{62}$ All of these

(2007)). Subjects interviewed two job candidates — one male and one female - who had equal credentials. $I d$. One set of subjects was "primed" to believe in their own objectivity. Id. Those manipulated to think of themselves as objective evaluated the male candidate higher. $I d$. This led to Negowetti's conclusion that "[i]ronically, it seems that thinking of oneself to be objective leads one to be more susceptible to biases." Id. at 712 .

56. This is a familiar phrase in motions in limine. See, e.g., Kelly v. New W. Fed. Sav., 49 Cal. App. 4th 659, 670 (1996).

57. See Negowetti, supra note 55, at 705 n.79 (citing Kristin A. Lane et al., Implicit Social Cognition and Law, 3 ANN. REV. L. \& SoC. SCI. 427 (2007)) (“Implicit social cognition ("ISC") is a field of psychology that examines the mental processes that affect social judgments but operate without conscious awareness or conscious control.").

58. Id. at 711 .

59. Id. (citing Ziva Kundra, Social Cognition: Making Sense of People 293 (Mass. Inst of Tech. Press 1999), and Jerry Kang, Trojan Horses of Race, 118 HARV. L. REV. 1489, 1499, 1515 (2005)). Negowetti noted that " $[\mathrm{w}]$ hen we discover evidence that supports our desired conclusions, we readily accept it, but when we come across comparable evidence that challenges our desired conclusions, we "work hard to refute it." Id. (citing KUNDRA, supra note 59, at 230). Kundra explored this at length - including looking at empirical studies -- and noted that we are "more likely to notice that a correlation is spurious when we are motivated to disbelieve it." KUNDRA, supra note 59 , at $228-232$.

60. This view is shared by Judge Posner. See Susan A. Bandes, Moral Imagination in Judging, 51 WASHBURN L.J. 1, 17 n.108 (2011) (noting Posner's acknowledgment of the "welldocumented tendency, once one has made up one's mind, to search harder for evidence that confirms rather than contradicts one's initial judgment"). Bandes also cited Guthrie et al., Blinking on the Bench: How Judges Decide Cases, 93 CoRnell L. Rev. 1, 8 (2007), for the proposition that "judges, like lay people, are influenced by unacknowledged intuitions." Id.

61. George Lakoff \& Mark Johnson, Philosophy in the Flesh 10-11 (Basic Books 1999). Lakoff and Johnson detailed numerous simultaneous processes our brain goes though "second by second" during any given conversation. $I d$. at 10. This includes "constructing mental images" and "filling in gaps in the discourse." Id. at 11.

62. See Gary L. Blasi, What Lawyers Know: Lawyering Expertise, Cognitive Science, and the Functions of Theory, 45 J. LEGAL EDUC. 313, 337 (1995). Blasi gives an example of imagining a scene from a movie where a baseball player takes a bite of an apple. Id. Most of us would envision a male baseball player eating a red apple. $I d$. This is based upon our default- expectations. 
choices are based upon your pre-conceived notions. ${ }^{63}$ As you continue walking, your mind makes countless other immediate assessments, and lickety-split, you have the lay of the land-business establishments, pedestrians, taxi-cabs, and city buses-without ever even "thinking" about any of this in the traditional sense. The majority of these assessments are instantaneous and non-verbal. We do not have to stop and label every stimulus. ${ }^{64}$ The "short-cuts" stored in your brain have already taken care of that. This permits you to focus on what is important to you in that moment-for example, is there a Starbucks where you might be able to grab a caramel macchiato before you get to your destination?

Cognitive scientists explain these "short-cuts" in various terms, such as "schemas," "frames," or "mental blueprints." ${ }^{65}$ Put in layman's terms, we have already sorted through what constitutes an Italian restaurant or a taxi-cab. So long as the stimuli we encounter falls within our pre-conceived expectations, identification is automatic. No more thought is necessary unless we are intrigued or these expectations are otherwise challenged. ${ }^{66}$

Our minds have similar "short-cuts" when it comes to social issues ${ }^{67}$ For example, we might be opposed to the death-penalty because of a myriad of logical reasons that we have already worked through. If only a logos-based reaction is triggered, we can debate the issue solely based on logic and it is possible that we could change our minds.

But the mere mention of certain social or moral issues can also involve pathos by triggering "short-cuts" to powerful emotional reactions. Just as with mental short-cuts, emotional short-cuts are rapid-fire, knee-jerk reactions that are personal to each individual. ${ }^{68}$ Such deeply-seeded emotional responses happen so quickly they are impossible to stop. They are the type of responses deemed by some cognitive scientists to be "system one" responses, meaning no deliberation is involved. ${ }^{69}$ We simply feel an instant and predictable emotion, which can

Id. Yet, as Blasi points out, it could easily be a scene from A League of Their Own, which concerned a female baseball team. Id.

63. Id. at 336-38.

64. See Deborah Tannen, What's in a Frame? Surface Evidence for Underlying Expectations, in New Directions in Discourse Processing 137-39 (Roy Freedle ed., 1979). Tannen noted: "expectation seems to corroborate a nearly self-evident truth: in order to function in the world, people cannot treat each new person, object, or event as unique and separate." Id. at 137. Thus, "[t]he only way we can make sense of the world is to see the connections between things, and between present things and things we have experienced before or heard about." Id.

65. See id. at 137-39.

66. Id. Tannen noted that even animals appear to use "frames" to understand signals, such as when another dog wants to play. Id. at 141.

67. See Negowetti, supra note 55, at 694-95.

68. Id. at 705-14.

69. Negowetti spoke of a "“dual process" of reasoning that is increasingly becoming recognized amongst cognitive scientists. $I d$. at 705. As presented:

According to such approaches ... System 1 is rapid, intuitive, and error-prone; System

2 is more deliberative, calculative, slower, and often more likely to be error-free. Many 
include outrage or even physical repulsion. The more we are exposed to these triggers, the more they can intensify. ${ }^{70}$ Our blood may boil, tears may well, or we may feel sick to our stomach.

Often, these knee-jerk emotional reactions are tethered to concrete visual images. ${ }^{71}$ For example, this Article previously referenced the Charleston killings and this nation's powerful emotional response. Most assumed the killings were racially motivated and that assumption was confirmed when new sources posted the images of Dylann Roof holding a gun while waving a Confederate flag. ${ }^{72}$ The image became bigger than life because it symbolized so much more. Our reaction was based not only upon the knowledge of the specific murders on that date, but on so many other incidents and events that are part of each of our own life experiences. In other words, we have a memory bank of perhaps thousands of times when we have felt sickened by the acts and effects of racism. Just as with other mental "shortcuts," that memory bank-and the accompanying physical reaction-was conjured in a fraction of a second. All of this violence was under the shadow of that Confederate flag. The image of Dylann Roof and that flag became the symbol, not only of the Charleston murders, but also of centuries of injustices experienced by African-Americans. ${ }^{73}$

Following Charleston, it would be difficult, if not impossible, for many simply to ignore the image of a Confederate flag. For example, if you were interviewing an individual for a job opening and you accidently spotted a small tattoo of a Confederate flag that the applicant had tried to conceal, would you have an emotional reaction? If you did, could you really set this aside in making a hiring decision? As noted above, the proverbial bell has been rung. ${ }^{74}$

implicit mental processes function outside of one's conscious focus and are rooted in System 1, including implicit memories, implicit perceptions, implicit attitudes, and implicit stereotypes. System 1 mental processes affect social judgments, but operate without conscious awareness or conscious control.

Id.

70. See Kenneth D. Chestek, Judging by the Numbers: An Empirical Study of the Power of Story, 7 J. Assn. Legal Writing Directors 1, 15 (2010). Chestek talked of "deep frames" that operate at an unconscious level and that are so powerful that they "often . . trump facts." Id.

71. Emotionally charged mental images trigger physiological responses, more particularly, the release of certain neuro-transmitters. Nancy Levit, The Theory and the Practice-Reflective Writing Across the Curriculum, 15 Legal Writing: J. Legal Writing Inst. 253 (2009). Levit noted that studies show that we retain only $20 \%$ of what we read, but $80 \%$ of symbols. Id. This is why trial lawyers strive to paint "pictures" for a jury. Id.

72. See supra notes 4-6 and accompanying text.

73. Id.

74. If you found yourself inclined not to hire the applicant, you may have already engaged in rationalization. See Negowetti, supra note 55, at 711. For example, you may have begun to justify your decision because the applicant openly espoused a viewpoint on a controversial topic. But the hypothetical was framed as an accidental discovery. If you question whether you used a rationalizing technique, ask yourself whether you would have the same reaction if the tattoo had conveyed an opposite message. 
Another feature of schemas, or frames, relates more directly to story. Schemas allow us to make inferences and fill-in-the-blanks. ${ }^{75}$ Based upon our fascination with narrative, we anticipate the outcome. ${ }^{76} \mathrm{We}$ know how the story should end. We also know how we want the story to end. First impressions are everything. That is exactly why a powerful introductory hook is so important.

Cognitive scientists are not alone in recognizing the important role of initial perception - so has Hollywood. In fact, the gold standard is to grab the viewer in the opening images. ${ }^{77}$ The first ten minutes of a movie are seen as critical as they frame the manner in which the viewer watches the film, specifically including getting the viewer to see the narrative through the perspective of the protagonist. ${ }^{78}$ The same is true for advertising. In less than thirty seconds, the viewer must be engaged and this often is accomplished by the careful use of images that tug on our heart-strings. ${ }^{79}$

An even better example is still photography. A Pulitzer Prize for photojournalism is awarded each year for a single image that grabs the viewer on a deeply emotional level. ${ }^{80}$ It is often said that such images "speak volumes." The same can be said about powerful writing. Carefully chosen words conjure up images, which in turn may have the same emotive effect as a Pulitzer Prize photo or an Academy Award-winning moment. Just as with movies, television ads, or prize-winning photos, the conjured-up images must grab the reader at "hello."

The skeptical reader might say all of this psycho-jumbo is fine and good for Hollywood, but it has no practical application in the hallowed halls of justice. The skeptical reader should read on. As set forth below, there is more than one reason to include pathos in the introductory paragraphs of a legal brief.

\section{Fact: A Powerful Emotional "Hello" Can Either Sway the Judiciary or-at Minimum-Provide the Judiciary with the Tools to Convince the Public of the Inherent Fairness of a Ruling}

In 2005, President Bush appointed Chief Justice John Roberts to the Supreme Court. ${ }^{81}$ At his confirmation hearings, the U.S. Senate Committee on the Judiciary questioned the future chief justice about the impact of a judge's personal views

75. LAKOFF \& JOHNSON, supra note 61 , at 10-11.

76. Berger, supra note 53, at 277. Berger noted that certain stories are so "embedded" in our culture that all that is necessary is to "simply name the characters, and the plot will spring to life." Id. at 278 .

77. See Hal Ackerman, Write Screenplays that Sell 95-96 (Tallfellow Press, Inc. 2003) (discussing the "inciting event" and how it must be set forth in the opening pages of a screenplay).

78. See id.

79. See id.

80. FAQ, PUlitZer (May 10, 2014), http://www.pulitzer.org/faq\#q25 [http://perma.cc/Z9CJG2SJ].

81. Wardlaw, supra note 35 , at 1630 n.5. 
on decision-making. ${ }^{82}$ In what has been deemed an "iconic moment," Roberts responded: "Judges are like umpires. Umpires don't make the rules, they apply them. ${ }^{, 83}$ Roberts assured the committee that he would "remember that it's my job to call balls and strikes and not to pitch or bat." ${ }^{14}$

Roberts' remarks generated a substantial amount of both mainstream and scholarly press. ${ }^{85}$ Many criticized the analogy. ${ }^{86}$ At least one legal commentator suggested the better analogy would be to a basketball referee.$^{87}$ Baseball umpires must call pitches based upon a very specific description of the strike zone that leaves no room for discretion. ${ }^{88}$ By contrast, basketball referees are often called upon to exercise substantial discretion. For example, in determining whether to call a foul, a basketball referee may be required to assess whether a player has

82. Confirmation Hearing on the Nomination of John G. Roberts, Jr. to be Chief Justice of the United States: Hearing Before the S. Comm. on the Judiciary, 109th Cong. 56 (2005).

83. Id. at 55; see also Eric Segall, Justices, Referees, and Umpires: The Role of Discretion in Sports and Supreme Court Decisions, DORF ON L. (Jan. 5, 2015), http://www.dorfonlaw. org/2015/01/justices-referees-and-umpires-role-of.html [http://perma.cc/MDY8-32UN].

84. Segall, supra note 83.

85. Id.; see also, e.g., Timothy P. Terrell, The Art of Legal Reasoning and the Angst of Judging: Of Balls, Strikes, and Moments of Truth, 8 Nw. J.L. \& Soc. PoL'y 35, 37 (2012).

86. Terrell, supra note 85 , at 37 ; see also Segall, supra note 83.

87. Segall, supra note 83.

88. Id.; but see Terrell, supra note 85 , at $39-40$. In defending the justice-umpire analogy, Terrell's article provided a fascinating analysis of a five-paragraph essay penned by Professor Stephen Jay Gould, where Gould mourned the passing of baseball umpire Babe Pinelli, who called the controversial final out in the only "perfect game" ever pitched in a World Series game. Id. at 39. The pitch was "high and outside," meaning it should have been called as a ball, not a strike. Id. Yet Gould fiercely defended the call and Pinelli's exercise of discretion. Id. In Gould's ending words:

Truth is inflexible. Truth is inviolable. By long and recognized custom, by any concept of justice, [the batter] had to swing at anything close. It was a strike - a strike high and outside. Babe Pinelli, umpiring his last game, ended with his finest, his most perceptive, his most truthful moment. Babe Pinelli, arbiter of history, walked into the locker room and cried.

Id. at 40. The winning pitcher was Don Larson and his amazing 1956 feat still stands. See Ben Cosgrove, 27 Up, 27 Down, Remembering Don Lawson's 1956 Perfect Game, Time (Oct. 7, 2014), http://time.com/3881128/don-larsen-perfect-game-october-8-1956/[http://perma.cc/KR2J-TDQ6]. Not only has there never been another perfect game in World Series history - meaning not a single batter even reaches first base - but there never even has been a no-hitter. Id. In fact, there has only been one other no-hitter pitched in post-season play. Id.

Another commentator argued the best analogy is to the Commissioner of Baseball, who enjoys substantial discretion in offering "interpretive guidance" as to how umpires call games. Aaron S.J. Zelinsky, The Justice as Commissioner: Benching the Judge-Umpire Analogy, 119 YalE L.J. ONLINE 113, 114-18 (2010). Zelinsky's article contains an interesting history to the umpire-judge comparison that dates back to 1886 . Id. at 114-15. Zelinsky noted early comparisons-which related to trial judges - argued that judges should do more than just be a "mere umpire." Id. 
"bend[ed] the body into a position that is not normal." 89 But "normal" is not defined by the rules. ${ }^{90}$ This correlates to how justices have to interpret vague phrases such as "equal protection," "due process," "unreasonable searches," and "cruel and unusual punishment.",

For some, suggesting that emotions play a role in judicial decisions raises the issue of judicial activism. ${ }^{92}$ In its ugliest form, judicial activism is the accusation that a judge truly ignored the law to further a personal agenda. ${ }^{93}$ In other words, a judge knows the right answer and purposefully rules another way. ${ }^{94}$ That is not the point this Article raises. As noted above, there is an argument that the Court correctly decided each of the cases discussed below. There also is an argument that each was not. Rather than suggesting that any of these decisions constituted impermissible judicial activism, this Article merely argues that the emotive appeals set forth in the briefs may have at least somewhat influenced the Supreme Court's decision, perhaps even on a subconscious level.

Numerous scholarly works support the argument that judges may be moved by emotional appeals. ${ }^{95}$ This is especially so in "open cases," meaning cases where existing precedent does not squarely answer the question. ${ }^{96}$ Where the law plainly permits two opposing results, it is difficult to ignore the possible role that emotions play. ${ }^{97}$ Put simply, when our hearts are moved, our mind often follows. ${ }^{98}$

There is another compelling argument that supports the thesis that emotions may indeed play a role in judicial decision-making. One need only look to the dissents written in any number of five-to-four Supreme Court decisions. As can

89. Segall, supra note 83 .

90. Id.

91. Id.

92. See Kermit Roosevelt III, The Myth of Judicial Activism 14-15 (Yale Univ. Press 2006). Roosevelt noted that "the Supreme Court has been castigated for activism almost continuously, from quite early on and by a wide variety of critics." Id. at 15 . The accusation typically is "little more than a rhetorically charged shorthand for decisions the speaker disagrees with." Id. at 3.

93. Id. at 38 .

94. Id. at 14 .

95. See, e.g., Quintilian and the Law: The Art of Persuasion in Law and Politics (Olga Tellegen-Couperus ed., 2003).

96. See, e.g., Andrea McArdle, Using A Narrative Lens to Understand Empathy and How It Matters in Judging, 9 LEgAL COMM. \& RHETORIC: JALWD 173, 178-79 (2012). McArdle referred to "clear" and "unclear cases," meaning where a decision either is or is not mandated by existing precedent. "In the unclear cases, empathy-informed by life experience and a capacity to appreciate others' perspectives and situations - helps guide the exercise of judgment or discretion." Id. at 178. By contrast, in "unclear cases" where a judge must exercise discretion or independent judgment, a judge "may invoke an 'individual sentiment of justice." Id. at 179 (quoting CARDOzO, supra note 2, at 21).

97. Id. at 178 .

98. See supra notes $48-49$ and accompanying text. 
be seen in the cases discussed below, the dissents flatly call out the majority for ignoring the law and instead deciding a case based upon personal views. ${ }^{99}$ This is not limited to a particular set of justices. In his dissent in Obergefell, Chief Justice Roberts made this accusation either directly or indirectly an astounding twenty-seven times. ${ }^{100}$ Justice Scalia followed suit in a scathing rebuke. ${ }^{101}$ The tables turned in Adoptive Couple where it is Justice Sotomayor, joined by Justice Ginsburg and Justice Kagan, as well as Justice Scalia, who argued that the majority permitted emotions to blind their legal reasoning. ${ }^{102}$ That majority included Chief Justice Roberts. ${ }^{103}$

And even if the justices were wrong-and no member of the Supreme Court ever allowed emotions to factor into judicial decision-making - there is a second reason why practitioners should include emotional hooks in their briefs. As a practical matter, these emotional hooks permit the Supreme Court to justify their rulings morally. In his book, "The Will of the People," Supreme Court historian Barry Friedman hinted at a reason: the Supreme Court is keenly aware that there is a check on the Supreme Court's power, namely, the American public. ${ }^{104}$

Friedman began his thesis by pointing to a critical juncture in Supreme Court history. ${ }^{105}$ In the late 1930 s, the Supreme Court began to chip away at President Roosevelt's widely popular New Deal legislation. ${ }^{106}$ Roosevelt saw a way out. ${ }^{107}$ He proposed a plan by which he would be allowed to add an additional justice for every sitting justice over the age of seventy. ${ }^{108}$ This would permit Roosevelt to stop the onslaught by packing the court with friendly justices. ${ }^{109}$ As this plan was being debated, the Supreme Court changed course. ${ }^{110}$ Instead of striking New Deal legislation, it upheld several measures. ${ }^{111}$ In turn, public opinion rallied

99. See infra notes 100-01.

100. Obergefell v. Hodges, 135 S. Ct. 2584, 2611-2625 (2015) (Roberts, C.J., dissenting) (the term appeared on the following pages and a parenthetical indicates how many times Roberts used it: 2611 (4), 2612 (4), 2616 (2), 2618-2619 (1), 2619 (2), 2620 (1), 2620-2621 (1), 2621(2), 2622 (2), 2622-2623 (1), 2624 (6), 2625 (1)). Roberts noted: "It can be tempting for judges to confuse our own preferences with the requirements of the law." Id. at 2612.

101. See id. at 2625-31.

102. Adoptive Couple v. Baby Girl, 133 S. Ct. 2552, 2571-72 (2013).

103. Id. at 2556 .

104. Barry Friedman, The Will of the People: How Public Opinion Has Influenced the Supreme Court and Shaped the Meaning of the Constitution 3-4 (Farrar, Straus \& Giroux eds., 1st ed. 2009). For an analysis of Friedman's work, see Amanda Frost, Defending the Majoritarian Court, 2010 Mich. ST. L. Rev. 757 (2010).

105. FRIEDMAN, supra note 104, at 3.

106. $I d$.

107. $I d$.

108. $I d$.

109. Id.

110. Id. at 4 .

111. Id. 
against the plan, which Congress then rejected. ${ }^{112}$ Friedman posited that a "tacit deal" was reached whereby "the American people would grant the justices their power, so long as the Supreme Court's interpretation of the Constitution did not stray too far from what a majority of the people believed it should be." ${ }^{113}$

Friedman also posited that the Supreme Court essentially tests the waters though a process he calls "judicial decision-popular response-judicial redecision. $" 114$ In other words, when the Court hands down a controversial decision, the public reacts, which then impacts how the Supreme Court decides future cases. If the reaction is negative, the Supreme Court pulls back. ${ }^{115}$ When positive, the Supreme Court senses the leeway that permits the justices to stray a bit further down the path forged by the controversial decision. ${ }^{116}$ Whether this is true is beside the point. The fact remains that judicial opinions are crafted in a manner to convince the American public that the decision is justified. In some cases, the legal inquiry involves interpretation of evolving societal norms. What better way of convincing the public of the correctness of a decision than by using pathos to tap into those norms?

Bottom line? Although judges may say emotional appeals have no bearing on their decision-making, appellate opinions are packed with moral justifications for legal rulings. The takeaway for many practitioners is "do as I do, not as I say." The top scribes who wrote the prevailing briefs analyzed below certainly followed this advice.

\section{The Use AND Impact OF POWERful "Hellos" IN the BRIEFS AND Opinions Written in Five ReCEnt Hotly Contested Five-TO-Four SuPREME COURT DECISIONS}

This section focuses on the brilliance-or lack thereof-of how each side framed the issues and utilized powerful emotional hooks in five hotly contested recent U.S. Supreme Court decisions. In other words, this section does not challenge the correctness of the Supreme Court decisions. Rather, this section focuses on the techniques used to control the lens by which the Court analyzed an issue. The opening hooks - the "hellos"-were designed to seal the deal at the onset. In turn, the Supreme Court used these hooks to make its case to the public as to why its decision was not only legally sound, but also fair.

In analyzing these briefs, this author identifies the "hello" as the first opportunity where the advocate truly makes his or her substantive case as to why his or her side should win. It is not the section covering "procedural history," "interested parties," or even the often cumbersome "question presented." Instead, it is the first spot where a reader really starts reading. In some briefs, this may be called the "summary of argument" or "statement of the case." Other briefs may

112. $I d$.

113. Id. (adding that "[f]or the most part, this deal has struck").

114. Id. at 382 .

115. Id. (citing Roe v. Wade, 410 U.S. 113 (1973), as an example).

116. Id. 
simply call this section the "introduction."

The "hello" is the one spot where the brief writer has the reader's undivided attention. It's akin to the first words out of an advocate's mouth at oral argument. Chief Justice Roberts recently cautioned that an advocate might only have at most a "couple of minutes" prior to being interrupted by the justices. ${ }^{117}$ The introductory portion of a brief may hold the reader's undivided attention for a bit longer. It is perfectly acceptable for an "introduction" or "summary of argument" to be several paragraphs long. Still, a top scribe knows to use this space wisely. $\mathrm{He}$ or she must grab the reader at the get-go and must hammer-home the emotional appeals throughout the brief.

The section discusses five cases: Obergefell v. Hodges ${ }^{118}$ (same-sex marriage); Adoptive Couple v. Baby Girl ${ }^{19}$ (parental rights under the Indian Child Welfare Act); AT\&T Mobility v. Concepcion ${ }^{120}$ (preemption/unconscionability of class-wide arbitration waivers); Burwell v. Hobby Lobby Stores, Inc. ${ }^{121}$ (religious freedom/abortion rights); and Glossip v. Gross ${ }^{122}$ (death penalty/drug protocol).

The briefing in three of these cases presented the justices with personal/familial rights where it is difficult to ignore the emotional appeal of the case and the widespread-yet very personal-ramifications of the Supreme Court's ruling. Glossip also involved an emotionally charged issue: the imposition of the death penalty. ${ }^{123}$ But, as Concepcion shows, pathos has its place even in run-of-the-mill contract cases. ${ }^{124}$

There cannot be enough said to underscore the importance of the briefing in five-to-four Supreme Court decisions. There are immediate consequences for the litigants and for all others directly affected by the ruling. Such cases also have a significant long-term impact. But for one vote-which perhaps could have been turned - the legal horizon may drastically change for years to come. For example, Bowers v. Hardwick was a 1986 five-to-four decision that held states could criminalize homosexual conduct. ${ }^{125}$ Only a few years later, Justice Powell, who

117. John F. Roberts, Jr., Oral Advocacy and the Re-emergence of a Supreme Court Bar, 30 J. Sup. Cт. Hist. 68, 71 (2005). Chief Justice Roberts stated: "Nowadays, the most uninterrupted time that an advocate is likely to get before the Supreme Court is a couple of minutes at the outset of argument." Id. Roberts further stated:

When I was preparing for Supreme Court arguments, I always worked very hard on the first sentence, trying to put in it my main point and any key facts, because I appreciated that the first sentence might well be the only complete one I got out in the course of the argument.

Id.

118. 135 S. Ct. 2584 (2015).

119. 133 S. Ct. 2552 (2013).

120. 563 U.S. 333 (2011).

121. 134 S. Ct. 2751 (2014).

122. 135 S. Ct. 2726 (2015).

123. Id.

124. Concepcion, 563 U.S. 333.

125. Bowers v. Hardwick, 478 U.S. 186, 190 (1986). 
cast the swing vote, frankly admitted he thought he had "made a mistake." ${ }^{126}$ That single vote-which obviously could have gone either way based upon the closeness of the decision - set back the move to establish civil rights for millions of gay and lesbian Americans by almost two decades. ${ }^{127}$

\section{A. Obergefell v. Hodges: Same-Sex Marriage}

The Court decided Obergefell just two years after two other related landmark cases involving gay rights: Hollingsworth v. Perry ${ }^{28}$ and United States v. Windsor. ${ }^{129}$ The Hollingsworth and Windsor cases were seen by many as dual cases. The Court delivered the opinions on the same day and many speak of them in one breath in both case law and secondary sources. ${ }^{130}$ As explained below, the briefing for Windsor and Hollingsworth - which dealt with more preliminary legal issues involving same-sex marriage-contained the emotional hooks that would pave the way for the Obergefell decision.

The "hellos" in both Hollingsworth and Windsor covered two major themes: the effect of the Supreme Court's ruling en masse, meaning the collective effect that the ruling would have on the entirety of the gay and lesbian community, as well as the effect on the individual litigants before the Court. ${ }^{131}$ Together, these "hellos" bashed existing stereotypes of gays and lesbians and explained exactly why the Court should interpret the Constitution to permit gays and lesbians to marry. ${ }^{132}$ It was not about money, sex, or even specific rights, such as the ability to be at the bedside of a dying partner. It was about dignity. ${ }^{133}$ It was about the

126. Of course, Justice Powell should be applauded for his frankness. Justice Powell's made this remark to his biographer in 1990 after his retirement from the Supreme Court. His actual words were: "I think I probably made a mistake in the Hardwick case." See Carol Nackenoff, Landmarks,

Portents, or Just Curves in the Road?, 45 Tulsa L. REV. 659, 666 (2010). This marked one of the few times a justice publically expressed regret for a prior vote.

127. The Court overturned Bowers seventeen years later in Lawrence v. Texas, 539 U.S. 558, 560 (2003). Notably, in perhaps a reference to Justice Powell's post-retirement comment, Justice Kennedy, writing for the majority, stated: "Bowers was not correct when it was decided, and it is not correct today. It ought not to remain binding precedent." Id.

128. 133 S. Ct. 2652 (2013).

129. 133 S. Ct. 2675 (2013).

130. See, e.g., William W. Bassett, California Community Property Law $\S$ 1:33 (Thomson Reuters 2015).

131. See Brief for Respondents, Hollingsworth v. Perry, 133 S. Ct. 2652 (2013) (No. 12-144), 2013 WL 648742 [hereinafter Respondents' Brief, Hollingsworth]; see also Brief on the Merits for Respondent Edith Schlain Windsor, United States v. Windsor, 133 S. Ct. 2675 (2013) (No. 12-307), 2013 WL 701228 [hereinafter Respondents' Brief, Windsor].

132. See Respondents' Brief, Hollingsworth, supra note 131; see also Respondents' Brief, Windsor, supra note 131.

133. See Respondents' Brief, Hollingsworth, supra note 131; see also Respondents' Brief, Windsor, supra note 131. 
stigma visited upon not only gays and lesbians but on their children. ${ }^{134}$

The initial briefing in Hollingsworth and Windsor was truly genius given the existing legal precedent and public sentiment. Deeply-held beliefs on same-sex marriage had to be reconciled with deeply-held beliefs about the dignity that should be afforded to every individual and family. Not only did the exceptional briefing win the day at the Supreme Court, but it also set in motion a wave of empathy and acceptance that would quickly turn on a dime America's view of gays and lesbians, in particular, those gay and lesbians who-like many of their heterosexual counterparts-were in committed monogamous life-long relationships. ${ }^{135}$ Notably, the Obergefell opinion would cite this shift in public opinion as part of its rationale for holding that gays and lesbians could no longer be denied the fundamental right to marry. ${ }^{136}$ Of course, credit must be given where credit is due. To understand the significance of the briefing in Obergefell, it is necessary to understand the impact of the powerful "hellos" in both Hollingsworth and Windsor.

1. The Impact of the "Hellos" in the Prevailing Briefs in Hollingsworth and Windsor.-On May 28, 2009, two lawyers staged a press conference at Los Angeles' famed Biltmore Hotel to announce a federal challenge to California's Proposition 8 that banned same-sex marriages. ${ }^{137}$ "They'll never win," said many. Legal experts weighed in: how can there possibly be a federal constitutional right to same-sex marriage? Even those for gay rights feared it was too soon. ${ }^{138}$ The Little Engine that Could. Just six years later, the U.S. Supreme Court held that same-sex marriage was not only constitutionally mandated in California, but throughout the nation. ${ }^{139}$

Hollingsworth dealt with the enforceability of California's Proposition 8, which amended California's state constitution to ban same-sex marriages expressly. ${ }^{140}$ Proposition 8 was put on the ballot in 2008 directly following the

134. See Respondents' Brief, Hollingsworth, supra note 131; see also Respondents' Brief, Windsor, supra note 131.

135. See generally Changing Attitudes on Gay Marriage, Pew Res. Ctr. (July 29, 2015), http:/www.pewforum.org/2015/07/29/graphics-slideshow-changing-attitudes-on-gay-marriage/ [http://perma.cc/7JS9-K36G].

136. Obergefell v. Hodges, 135 S. Ct. 2584, 2596-97 (2015); see also id. at 2615 (Roberts, C.J., dissenting).

137. Carol J. Williams, Gay Marriage Battle Relaunches Today as Prop. 8 is Challenged in Court, L.A. TIMES (May 27, 2009, 7:58 AM), http://latimesblogs.latimes.com/lanow/2009/05/newfront-in-prop-8-battle-launched-today-with-federal-suit.html [http://perma.cc/2GFL-96PN].

138. Notably, the American Civil Liberties Union and LAMBDA Legal, among others, issued statements criticizing the filing as "premature" and speculating that it posed a "very high risk" of creating negative Supreme Court precedent. See Lisa Leff, Ted Olson and David Boies, Bush v. Gore Lawyers, Join Forces to Challenge Proposition 8, Huffington Post (May 25, 2011, 1:25 PM) http://www.huffingtonpost.com/2009/05/28/theodore-olson-and-david-_n_208450.html [http://perma.cc/EE5E-53CE].

139. Obergefell, 135 S. Ct. at 2608.

140. Respondents' Brief, Hollingsworth, supra note 131, at 1. 
Supreme Court of California's decision in In Re Marriage Cases that held there was a state right to same-sex marriage. ${ }^{141}$ In the less than six-month period of time between the Supreme Court of California's decision and the passage of Proposition 8, over 18,000 same-sex couples married. ${ }^{142}$ The Supreme Court of California revisited this issue in Strauss v. Horton. ${ }^{143}$ Those against Proposition 8 asked that the court lift the voter-imposed ban on same-sex marriage. ${ }^{144}$ Proponents of Proposition 8 did more than disagree. ${ }^{145}$ They demanded that the court nullify all of the interim marriages. ${ }^{146}$ Although the Supreme Court of California declined to do the latter, the court found that Proposition 8 was constitutionally sound, thereby bringing the notion of same-sex marriages in California to a screeching halt. ${ }^{147}$

Enter David Boies and Ted Olson.

The filing of Hollingsworth was announced on May 28, 2009, just two days after the Supreme Court of California's adverse decision in Strauss. ${ }^{148}$ Both the governor and attorney general refused to defend the lawsuit. ${ }^{149}$ Instead, the official proponents of Proposition 8 ("Proponents") defended it. ${ }^{150}$ Ultimately, the Court decided Hollingsworth on procedural grounds, more particularly, that the proponents lacked standing. ${ }^{151}$ Although the Hollingsworth decision rendered same-sex marriage legal in California, the failure to reach the merits effectively punted the issue of nationwide same-sex marriage until another day.

Windsor involved the constitutionality of the Defense of Marriage Act ("DOMA"). ${ }^{152}$ Like Hollingsworth, Windsor arguably could also have been disposed of on procedural grounds. ${ }^{153}$ Instead, the Windsor majority squarely took on the merits and squarely adopted the "hello" set forth by Boies and Olson in their brief for Hollingsworth. When read in conjunction with the equally powerful "hello" in Windsor, it is easy to see why these "hellos" were followed in the briefing in Obergefell.

a. The Hollingsworth "hello" and its impact on Windsor.-As noted above, the Court announced Hollingsworth on the heels of the Supreme Court of California's ruling in Strauss that found Proposition 8 constitutional. ${ }^{154}$ In that

141. See Strauss v. Horton, 207 P.3d 48, 59 (Cal. 2009), abrogated by Obergefell, 135 S. Ct. 2584.

142. Respondents' Brief, Hollingsworth, supra note 131, at 5.

143. Strauss, 207 P.3d at 59.

144. See id. at 62-65.

145. Id. at 199 .

146. Id. at 119-22.

147. Id. at 119 .

148. Hollingsworth v. Perry, 133 S. Ct. 2652, 2660 (2013).

149. Id.

150. $I d$.

151. Id. at 2668 .

152. United States v. Windsor, 133 S. Ct. 2675, 2683 (2013).

153. Id. at 2684-89.

154. Respondents' Brief, Hollingsworth, supra note 131, at 5. 
ruling, the Supreme Court of California noted that California recognized samesex civil unions and provided same-sex couples all of the benefits that it provided to heterosexual married couples. ${ }^{155}$ The only issue was "nomenclature." ${ }^{156} \mathrm{~A}$ partnership between a same-sex couple carried the name "civil union," while a partnership between a heterosexual couple carried the name "marriage." Many said: what difference does it make so long as the state provides same-sex couples the same rights as heterosexual couples?

The "hello" in Hollingsworth provided the answer.

Boies and Olson packed several powerful — and somewhat novel-emotional appeals into seven relatively short introductory paragraphs. ${ }^{157}$ These paragraphs emphasized the stigmatizing effect of distinguishing between same-sex partnerships and heterosexual partnerships ${ }^{158}$ Front-and-center was that the idea that gays and lesbians - and their children-deserved to be treated with dignity and equality under the law. ${ }^{159}$ The message was clear. So long as the distinction was in place, gays and lesbians - and their children - were deemed second-class citizens. ${ }^{160}$ These powerful first paragraphs set forth below used emphasis to identify the words, themes, and passages that would later be reflected in the Supreme Court opinions. ${ }^{161}$ As stated:

This case is about marriage, "the most important relation in life," a relationship and intimate decision that this Court has variously described at least 14 times as a right protected by the Due Process Clause that is central for all individuals' liberty, privacy, spirituality, personal autonomy, sexuality, and dignity; a matter fundamental to one's place in society; and an expression of love, emotional support, public commitment, and social status.

This case is also about equality. After a $\$ 40$ million political campaign during which voters were urged to "protect our children" from exposure to the notion that "gay marriage is okay," and "the same as traditional marriage," and thus deserving of equal dignity and respect, Proposition 8 engraved into California's constitution the cardinal principle that unions among gay men and lesbians are not valid or recognized as

155. Strauss v. Horton, 207 P.3d 48, 100 (Cal. 2009), abrogated by Obergefell v. Hodges, 135 S. Ct. 2584 (2015).

156. Id. at 75 ; see also id. at 128 (Werdegar, J., concurring) (specifically referring to the term "nomenclature").

157. Respondents' Brief, Hollingsworth, supra note 131, at 1-4.

158. $I d$.

159. Id. at 1 .

160. Id.

161. Id. at 1-4. Except where otherwise noted in this Article, emphasis is not in the original. Instead, emphasis has been added to the passages analyzed to highlight particular words, themes, and arguments set forth in the "hellos" and later adopted by Supreme Court opinions. For brevity, all footnotes, internal citations, and citations to the record also have been omitted. 
marriages, and therefore second-class and not equal to heterosexual marriages. Proposition 8 thus places the full force of California's constitution behind the stigma that gays and lesbians, and their relationships, are not "okay," that their life commitments "are not as highly valued as opposite-sex relationships," and that gay and lesbian individuals are different, less worthy, and not equal under the law, that "generates a feeling of inferiority" among gay men and lesbians-and especially their children - "that may affect their hearts and minds in a way unlikely ever to be undone."162

The final paragraphs in this "hello" continued to hammer-home the emotionally-charged themes of dignity, stigma, and the debilitating effects on both same sex-couples and their children. As stated:

The only substantive question in this case is whether the State is entitled to exclude gay men and lesbians from the institution of marriage and deprive their relationships - their love-of the respect, and dignity and social acceptance, that heterosexual marriages enjoy ... [T]he only harms demonstrated in this record are the debilitating consequences Proposition 8 inflicts upon tens of thousands of California families, and the pain and indignity that discriminatory law causes the nearly $\underline{40,000}$ California children currently being raised by same-sex couples.

The unmistakable purpose and effect of Proposition 8 is to stigmatize gay men and lesbians-and them alone-and enshrine in California's Constitution that they are "unequal to everyone else," that their committed relationships are ineligible for the designation "marriage," and that they are unworthy of that "most important relation in life."163

As noted above, the Court decided Hollingsworth on procedural grounds. ${ }^{164}$ California elected not to defend Proposition 8 in the federally-filed action. ${ }^{165}$ Yet the eloquence of the words in the Hollingsworth "hello" did not fall on the proverbial Hollywood "cutting room floor." Justice Kennedy's first used these concepts and themes in his majority opinion in Windsor and then later in Obergefell. ${ }^{166}$

In Windsor, Justice Kennedy used themes from the Hollingsworth "hello" to make his case that DOMA was unconstitutional. ${ }^{167}$ Front-and-center were the

162. Respondents' Brief, Hollingsworth, supra note 131, at 1 (emphasis added) (citations omitted).

163. Id. at 3-4. In this passage, the italicized emphasis was in the original. The underlined and bold emphasis has been added by the author.

164. Hollingsworth v. Perry, 133 S. Ct. 2652, 2668 (2013).

165. Id. at 2667-68.

166. See infra notes 167-78.

167. United States v. Windsor, 133 S. Ct. 2675, 2694 (2013). 
themes that the failure to allow same-sex couples to marry impacted their dignity and had a stigmatizing effect not on only gay and lesbian couples, but also their children. ${ }^{168}$ As poignantly stated by Justice Kennedy in the majority opinion:

DOMA's principal effect is to identify a subset of state-sanctioned marriages and make them unequal. The principal purpose is to impose inequality, not for other reasons like governmental efficiency. Responsibilities, as well as rights, enhance the dignity and integrity of the person. And DOMA contrives to deprive some couples married under the laws of their State, but not other couples, of both rights and responsibilities. By creating two contradictory marriage regimes within the same State, DOMA forces same-sex couples to live as married for the purpose of state law but unmarried for the purpose of federal law, thus diminishing the stability and predictability of basic personal relations the State has found it proper to acknowledge and protect. By this dynamic DOMA undermines both the public and private significance of statesanctioned same-sex marriages; for it tells those couples, and all the world, that their otherwise valid marriages are unworthy of federal recognition. This places same-sex couples in an unstable position of being in a second-tier marriage. The differentiation demeans the couple, whose moral and sexual choices the Constitution protects, and whose relationship the State has sought to dignify. And it humiliates tens of thousands of children now being raised by same-sex couples. The law in question makes it even more difficult for the children to understand the integrity and closeness of their own family and its concord with other families in their community and in their daily lives. ${ }^{169}$

An ending passage in Justice Kennedy's majority opinion again echoed the theme of dignity, stigmatization, and the effect on the children of same-sex couples used in Boies" "hello" in Hollingsworth. ${ }^{170}$ As emphatically noted by Justice Kennedy:

DOMA singles out a class of persons deemed by a State entitled to recognition and protection to enhance their own liberty. It imposes a disability on the class by refusing to acknowledge a status the State finds to be dignified and proper. DOMA instructs all federal officials, and indeed all persons with whom same-sex couples interact, including their own children, that their marriage is less worthy than the marriages of others. The federal statute is invalid, for no legitimate purpose overcomes the purpose and effect to disparage and to injure those whom the State, by its marriage laws, sought to protect in personhood and dignity. By seeking to displace this protection and treating those persons as living in marriages less respected than others, the federal statute is in violation of

168. $I d$.

169. Id. (emphasis added) (citations omitted).

170. Id. at 2695 . 
the Fifth Amendment. ${ }^{171}$

In all, Justice Kennedy mentioned the word "children" nine times, even though the married couple in Windsor-Edith Windsor and Dr. Thea Spyer-had no children. ${ }^{172}$ What is also striking is Justice Kennedy's reference to the "tens of thousands" of children currently being raised by same-sex couples. ${ }^{173}$ This tracks the Hollingsworth "hello," which mentioned there were "tens of thousands" of California families where "nearly 40,000" children were currently being raised by same-sex couples. ${ }^{174}$ If there were 40,000 such children in California alone, presumably there would be hundreds of thousands-not tens of thousands-across the nation. This was confirmed in an amicus brief filed two years later in Obergefell. ${ }^{175}$ Given the reference to "tens of thousands," it would seem fairly clear the impetus for this passionate passage flowed directly from the emotional appeal set forth by Boies and Olson in their Hollingsworth "hello."

Justice Kennedy also mentioned the word "dignity" twelve times, ${ }^{176}$ a count that he matched in Obergefell. ${ }^{177}$ The count for the use of the word "children" would grow even higher. ${ }^{178}$

b. The impact of the Hollingsworth "hello" on Obergefell-_Obergefell concerned the broader issue of whether same-sex marriage would be recognized across the nation. ${ }^{179}$ By this time, public opinion changed due to many reasons beyond the scope of this Article. More Americans than not supported same-sex marriages. ${ }^{180}$ If Friedman's hypothesis regarding "judicial decision-popular response-judicial re-decision" is to be accepted, this gave the Supreme Court the leeway needed to announce a constitutional right to same-sex marriage. ${ }^{181} \mathrm{Or}$, it at least made it much easier.

As in Windsor, Kennedy put the stroke of his quill on the majority opinion. ${ }^{182}$

171. Id. at 2695-96 (emphasis added).

172. This count includes any derivative of the word "children," such as "child." The same device is applied to the other comparisons discussed infra. The references to "child" or "children" can be found in id. at 2680, 2689, 2691, 2694-96.

173. Id. at 2694 .

174. Respondents' Brief, Hollingsworth, supra note 131, at 3.

175. Obergefell v. Hodges, 135 S. Ct. 2584, 2601 (2015).

176. This count includes the words "dignity," "indignity," "dignify," and "dignified." The references can be found at Windsor, 133 S. Ct. at 2689, 2692-94, 2696.

177. See Obergefell, 135 S. Ct. 2584.

178. See id.

179. Id.

180. Justice Kennedy noted a "shift in public attitudes toward greater tolerance." Id. at 2596. As of May 2015-one month prior to the Obergefell decision-Gallup reported that $60 \%$ of Americans supported same-sex marriage. See Justin McCarthy, Record-High 60\% of Americans Support Same-Sex Marriage, GALLuP (May 19, 2015), http://www.gallup.com/poll/183272/recordhigh-americans-support-sex-marriage.aspx [http://perma.cc/R4B4-RRUV].

181. FRIEDMAN, supra note 104, at 381-82.

182. Obergefell, $135 \mathrm{~S}$. Ct. at 2591. 
Again, the opinion would be eloquent. Again, he used the word "dignity" eleven times. ${ }^{183}$ Yet this time, Justice Kennedy made mention of the word "children" twenty-eight times. ${ }^{184}$ In no uncertain terms, one slam-dunk reason to find bans on same-sex marriage unconstitutional was the need to protect the children of same-sex couples. This echoed the poignant appeal in the Hollingsworth "hello" that implicitly posed the simple question: how can we not right the wrong committed when innocent children are stigmatized because of governmental discrimination directed at their parents?

In terms of emotional appeal, Justice Kennedy went one step further than he had in Windsor, perhaps responding to yet another point Boies and Olsen made in their Hollingsworth "hello." In the third paragraph, Boies and Olson chided the proponents of Proposition 8 by noting that nowhere in their sixty-five page opposing brief was there a single mention of the word "love." "185 Although Justice Kennedy never used that word in Windsor, he expressly used the word seven times in Obergefell and alluded to it at least seven more. ${ }^{186}$

The "hello" in Hollingsworth also made the argument that marriage is not simply about sexual intimacy. ${ }^{187}$ In the words of Boies and Olsen, marriage is about all of the other things, such as "love," "emotional bonding," and "commitment." "188 This nudges the reader to fill-in-the-blanks from his or her own life experience. Marriage is not just about sex; it is about getting kids to school in the morning and picking them up from soccer practice in the afternoon. It is about fighting, yet knowing you will still stay together. The inference that arises is that marriage is no different for gays and lesbians than their heterosexual counterparts. And Justice Kennedy stated exactly that in Obergefell:

The right to marry thus dignifies couples who "wish to define themselves by their commitment to each other." Marriage responds to the universal fear that a lonely person might call out only to find no one there. It offers the hope of companionship and understanding and assurance that while both still live there will be someone to care for the other. ${ }^{189}$

Other points set forth in the Hollingsworth "hello" can be seen in the Obergefell opinion. For example, Boies and Olsen argued that rather than wishing

183. Id. at 2594-97, 2599-600, 2603, 2606, 2608.

184. The references include further derivative versions of "child," including "childrearing," “childbearing," and "childhood." Id. at 2594-95, 2597, 2598, 2599, 2600-03, 2606-07.

185. Respondents' Brief, Hollingsworth, supra note 131, at 2.

186. The express count includes the terms "love" and "loving." These references can be found at Obergefell, 135 S. Ct. at 2594-95, 2600, 2607-08. However, this count obviously does not include references to Loving v. Virginia, 388 U.S. 1 (1967), cited heavily in the majority opinion. The indirect references can be found at Obergefell, 135 S. Ct. at 2594, 2596, 2599-600. There also is a reference to "romantic" considerations. Id. at 2607.

187. Respondents' Brief, Hollingsworth, supra note 131, at 2-3.

188. Id. at 2 .

189. Obergefell, 135 S. Ct. at 2600 (quoting United States v. Windsor, 133 S. Ct. 2675, 2689 (2013)) 
to denigrate the institution of marriage, gays and lesbians who want to marry actually respect the institution, so much so that they wish to experience the accordant benefits, including status and societal acceptance. ${ }^{190}$ As stated in the Hollingsworth "hello":

Plaintiffs agree with Proponents that marriage is a unique, venerable, and essential institution. They simply want to be a part of it - to experience all the benefits the Court has described and the societal acceptance and approval that accompanies the status of being "married." 191

In Justice Kennedy's words:

Were their intent to demean the revered idea and reality of marriage, the petitioners' claims would be of a different order. But that is neither their purpose nor their submission. To the contrary, it is the enduring importance of marriage that underlies the petitioners' contentions. This, they say, is their whole point. Far from seeking to devalue marriage, the petitioners seek it for themselves because of their respect-and need-for its privileges and responsibilities. ${ }^{192}$

One page later, Justice Kennedy also stated: "Their stories reveal that they seek not to denigrate marriage but rather to live their lives, or honor their spouses' memory, joined by its bond." 193

This theme was one of the many advanced by the Hollingsworth "hello" reiterated in the closing paragraph of the Obergefell opinion. Justice Kennedy again touched upon the universally accepted notion that marriage is about love $\mathrm{e}^{194}$ and that love goes far beyond sexual intimacy. ${ }^{195}$ For that reason, same-sex couples, like their heterosexual counterparts, could not be denied the right to marry. ${ }^{196}$ Justice Kennedy's "goodbye" in Obergefell soundly echoed the powerful "hello" set forth by Boies and Olsen in Hollingsworth:

No union is more profound than marriage, for it embodies the highest ideals of love, fidelity, devotion, sacrifice, and family. In forming a marital union, two people become something greater than once they were. As some of the petitioners in these cases demonstrate, marriage embodies a love that may endure even past death. It would misunderstand these men and women to say they disrespect the idea of marriage. Their plea is that they do respect it, respect it so deeply that they seek to find its fulfillment for themselves. Their hope is not to be condemned to live in loneliness, excluded from one of civilization's

190. Respondents' Brief, Hollingsworth, supra note 131, at 3.

191. Id.

192. Obergefell, 135 S. Ct. at 2594.

193. Id. at 2595 .

194. Id. at 2608 .

195. Id.

196. Id. 
oldest institutions. They ask for equal dignity in the eyes of the law. The Constitution grants them that right. ${ }^{197}$

As discussed more fully below, the Obergefell opinion would take extraordinary care to make readers see gays and lesbians as individual human beings, not just a face-less minority. This makes it easier to see why such individuals are deserving of the dignity that should be afforded to every human being. The template for that can be seen in the "hello" filed in the companion brief in Windsor.

c. The Windsor "hello" and its impact on both Windsor and Obergefell._Although the Hollingsworth "hello" received more Supreme Court "airtime," the impact of the equally powerful "hello" in Windsor should not be ignored. It breathed life into the Hollingsworth "hello" by allowing us to visualize the pain and indignities suffered by real people. More specifically, the "hello" told us the story of Edith S. Windsor and her spouse, Dr. Thea Spyer. ${ }^{198}$

The "hello" in Windsor began with a five-line "Statement of the Case," followed by the "Factual Background." ${ }^{199}$ Edie was Thea's widow. ${ }^{200}$ The couple legally married in Toronto, Canada, but the federal government did not recognize their marriage because of DOMA. ${ }^{201}$ The short "Statement of the Case" included the following simple hook which hinted at gender discrimination:

Both the district court and the court of appeals held that the equal protection component of the Fifth Amendment's due process clause was violated when the federal government imposed $\$ 363,053$ in estate taxes on the estate of Thea Spyer simply because she was married to a woman (respondent Edith S. Windsor), instead of to a man. ${ }^{202}$

The remainder of the Windsor "hello" nicely covered what was absent in the Hollingsworth "hello." The factual background gave the reader vivid and emotive details about the exact type of discrimination that Edie and Thea experienced throughout their long life with each other. Concrete facts allowed the reader to visualize the couple easily and see and feel what they had endured. In doing so, the briefing in Windsor showed us-rather than just told us-of the detrimental effect on dignity spoken of in the Hollingsworth "hello." The very first sentence stated:

In the early $1960 \mathrm{~s}$, at a time when lesbians and gay men risked losing their families, friends, and livelihoods if their sexual orientation became known, respondent Edith Windsor and her late spouse Thea Spyer fell in love and embarked upon a relationship that would last until Dr. Spyer's

197. Id. (emphasis added).

198. Respondents' Brief, Windsor, supra note 131, at 1-5.

199. Id.

200. Id. at 1 .

201. $I d$. at $5-6$.

202. Id. at 1 (emphasis added). 
death forty-four years later. ${ }^{203}$

These simple facts spoke volumes. Dovetailing with the Hollingsworth "hello," the word "love" was front-and-center. The Windsor "hello" also naturally sounded many of the themes discussed above. The couple courted, fell in love, and married in much the same manner as their heterosexual counterparts. ${ }^{204}$ Also, Edie and Thea truly respected the institution of marriage. Left unsaid-but blinking as bright as neon lights on the Las Vegas Strip-was the commonly known fact that many heterosexual marriages end in divorce. Yet, Edie and Thea had been together for forty-four years. ${ }^{205}$ How could the federal government not afford Edie the dignity of recognizing her state-sanctioned marriage?

The "hello" then went on to paint the picture of the discrimination-insults to dignity - that the couple endured throughout their lives. ${ }^{206}$ Both women were highly educated. ${ }^{207}$ Not only was Thea a doctor, but Edie received a graduate degree in mathematics and worked at IBM, thereby "achieving the highest technical rank at the company, notable for a woman at the time." ${ }^{208}$ Yet an executive order precluded companies that had government contracts to employ gays or lesbians. ${ }^{209}$ Using 1990s parlance, when the Federal Bureau of Investigation interviewed Thea for a security clearance, they "didn't ask" and she "didn't tell." ${ }^{210} \mathrm{Had}$ she done so, this highly educated and talented woman would have lost her job. ${ }^{211}$

The "hello" further presented the effect of discrimination and the couple's consequent need to hide their commitment. ${ }^{212}$ Sounding the theme from the Hollingsworth "hello," it was clear Edie and Thea got the message. They were "second-class citizens" and their love and commitment was inferior to that of their heterosexual counterparts:

Threats of disclosure and harassment also forced gay people like Ms. Windsor and Dr. Spyer to lead important parts of their lives in secrecy. Ms. Windsor and Dr. Spyer met at one of the few restaurants in New York City where lesbians were welcomed in 1963. Four years later, they moved in together and became engaged, although there was then no prospect of their being able to marry legally. To avoid unwelcome questions about the identity of Ms. Windsor's "fiancé" from co-workers, Dr. Spyer proposed with a diamond brooch, instead of a diamond ring. ${ }^{213}$

203. Id. (emphasis added).

204. Id.

205. Id.

206. Id. at 1-2.

207. Id. at 1 .

208. Id. at 2 .

209. Id.

210. Id.

211. Id.

212. Id. at 2-3.

213. Id. (emphasis added). 
The "hello" also emphasized that Edie and Thea were much like a normal couple, albeit subject to social persecution unless they hid both their love and the fact they were in a committed relationship. ${ }^{214}$ As stated:

Ms. Windsor and Dr. Spyer's life together was full of all the joys and sorrows that any couple faces. They worked, paid their taxes, traveled, entertained friends, and participated in their community. Ms. Windsor spent her career at IBM. Dr. Spyer, who earned a doctorate in clinical psychology, maintained an active private practice. ${ }^{215}$

Nor could it be doubted their love was as deep as with any heterosexual relationship. When Thea fell sick, Edie was her caretaker ${ }^{216}$ and the love Edie felt indisputably lasted beyond Thea's death. ${ }^{217}$ As persuasively stated:

In 1977, Dr. Spyer was diagnosed with progressive multiple sclerosis, a disease of the central nervous system that causes irreversible neurological damage and often, as in Dr. Spyer's case, paralysis. Ms. Windsor supported Dr. Spyer as her disability worsened, requiring first a cane, then crutches, then a manual wheelchair, then a motorized wheelchair that Dr. Spyer could operate with her one usable finger ...

Eventually, Dr. Spyer's health had so deteriorated that it became clear she would not live long enough to hold their wedding ceremony in New York, as the couple had long hoped. Therefore, joined by a physician and several close friends, Dr. Spyer, then seventy-five, and Ms. Windsor, then seventy-seven, flew to Toronto, Canada, where they were wed on May 22, 2007.

They spent their last two years together as a married couple. Dr. Spyer died of a heart condition on February 5, 2009. Grief-stricken, Ms. Windsor suffered a severe heart attack and received a diagnosis of stress cardiomyopathy, or "broken heart syndrome." 218

Although the emotional appeal may have moved the justices, most all of these powerful facts did not make it into Justice Kennedy's majority opinion in Windsor ${ }^{219}$ Still, the rather sparse facts presented did include the forty-four-year length of their marriage, a fact that technically was not at all relevant to the legal issue of DOMA's constitutionality. ${ }^{220}$ Justice Kennedy also pointed out another

214. Id. at 3 .

215. Id.

216. Id.

217. Id. at 4 .

218. Id. at 3-4 (emphasis added). As set forth in the brief, their life together became the subject of an award-winning documentary film, Edie and Thea: A Very Long Engagement (2009).

219. United States v. Windsor, 133 S. Ct. 2675 (2013).

220. Id. at 2683 . 
technically irrelevant fact: Edie and Thea registered as domestic partners as soon as they were given the opportunity to do so. ${ }^{221}$ As set forth in the majority opinion:

Edith Windsor and Thea Spyer met in New York City in 1963 and began a long-term relationship. Windsor and Spyer registered as domestic partners when New York City gave that right to same-sex couples in 1993. Concerned about Spyer's health, the couple made the 2007 trip to Canada for their marriage, but they continued to reside in New York City. The State of New York deems their Ontario marriage to be a valid one. ${ }^{222}$

Did the Windsor "hello" impact the written decision? When read in conjunction with the Hollingsworth "hello," it certainly appears it did. Instead of portraying gays and lesbians as irreverent outcasts, the "hellos" portrayed them as ordinary people living normal, everyday lives who simply wanted legal recognition for themselves and for their families. This frame-specifically including the in-depth story of such couples that was seen in the Windsor "hello"-would serve as the template for not only the briefing in Obergefell, but also for the powerful and passionate "hello" that Justice Kennedy set forth in his majority opinion.

2. The Impact of the Obergefell "Hellos."-On June 25, 2015, Twitter was on fire with hopeful predictions, including the hashtags "\#MarriageEquality," "\#LoveWins," and "\#Obergefell." ${ }^{223}$ Would tomorrow be the day? The Court handed down both Windsor and Hollingsworth on June 26, the day the Court handed down Lawrence v. Texas, which overruled Bowers v. Hardwick, over a decade earlier. ${ }^{224}$ How fitting would it be to hand down a favorable decision on the anniversary of these other landmark cases? James Obergefell and his lawyers camped out at the Supreme Court steps the entire week. ${ }^{225}$ News media charmed the American public with vivid explanations of the "running of the interns.",226 Protestors for both sides stood at the designated area just beyond the marbled steps of the Supreme Court. ${ }^{227}$ Then it happened. ${ }^{228}$ At 10:00 a.m. on June 26,

221. $I d$.

222. $I d$.

223. The following post references Twitter and the hopeful anticipation for a June 26, 2015 ruling. David Lat, Why The Same-Sex Marriage Decision Will Likely Come Out on June 26, ABove LAw (June 25, 2015, 5:00 PM), http://abovethelaw.com/2015/06/why-the-same-sex-marriagedecision-will-likely-come-out-tomorrow/ [http://perma.cc/HZW9-SDHE].

224. Lawrence v. Texas, 539 U.S. 556 (2003).

225. See Sandra Sobieraj Westfall, Jim Obergefell, Namesake of Historic Gay Marriage Case, Will Wait in Line Every Day To Be Front-Row for Supreme Court Decision, PeOPLE (June 15, 2015, 2:20 PM), http://www.people.com/article/jim-obergefell-determined-to-be-in-front-row-forsupreme-court-gay-marriage-decision [http://perma.cc/44GE-WZGL].

226. See Erin Dooley, Running of the Interns: This Is What a Mad Dash Outside the Supreme Court Looks Like, ABC News (June 25, 2015, 3:00 PM), http://abcnews.go.com/Politics/runninginterns-mad-dash-supreme-court/story?id=32024853 [http://perma.cc/JC8F-M5QU].

227. Adam Liptak, Supreme Court Ruling Makes Same-Sex Marriage a Right Nationwide, 
2015, the Court announced that Obergefell was one of four cases it would hand down and it would be the first read in the hallowed Court Chambers. ${ }^{229}$ By 10:01 $\mathrm{AM}$, the world knew. ${ }^{230}$ Bans on same-sex marriage were unconstitutional, thereby legalizing same-sex marriage nationwide. ${ }^{231}$

By the time Obergefell made its way to the Supreme Court, many courts and legal commentators believed that Windsor mandated a finding that there was a constitutional right for gays and lesbians to marry. ${ }^{232}$ Of course, this turned on how the legal issue would be framed. If the legal question was whether there was a fundamental historic right to same-sex marriage, the answer was no. If the legal question was instead whether there was a fundamental right to marry, which therefore could not be denied to gays and lesbians, the answer was yes. Foreshadowing Obergefell, Windsor appeared to embrace the latter, emphasizing that interpretation of the Constitution must be based upon "evolving" social norms. ${ }^{233}$

In total, the Supreme Court granted certiorari in four cases to address the issue of whether bans on same-sex marriage were constitutional. ${ }^{234}$ The Court deemed the Obergefell case the lead case. ${ }^{235}$ The "hello" in this brief not only powerfully hammered-home the themes that won in Windsor, but the "hello" also answered the question: why here; why now?

The relatively short "hello" was styled as an introduction and included only three paragraphs ${ }^{236}$-albeit very powerful paragraphs. The first of these paragraphs focused on the themes previously set forth in the Hollingsworth "hello" and adopted by Justice Kennedy in Windsor, specifically including "dignity" and "children." ${ }^{\text {"237 }}$ The Obergefell "hello" spoke of "love" and set up the stories of the individual effects of discrimination. ${ }^{238}$ It also used the term "legal strangers" and the vivid verb "erases" that Justice Kennedy later used in the Obergefell opinion. ${ }^{239}$ As the first paragraph of the Obergefell "hello" succinctly

N.Y. TimES, June 26, 2015, at A1, available at http://www.nytimes.com/2015/06/27/us/supremecourt-same-sex-marriage.html [http://perma.cc/NWC7-US38].

228. Id.

229. Id.

230. This author's text messages document the news as of 10:01 AM EST.

231. Obergefell v. Hodges, 135 S. Ct. 2584, 2608 (2015).

232. Justice Scalia's dissent in Windsor foretold this result. United States v. Windsor, $133 \mathrm{~S}$. Ct. 2675, 2709-10 (2013) (Scalia, J., dissenting). In fact, Justice Scalia even set forth a red-line version of exactly how the majority opinion in Windsor could be changed to invalidate a state law banning same-sex marriage. Id.

233. See id. at 2692-93.

234. Obergefell, 135 S. Ct. at 2593.

235. Brief for Petitioners, Obergefell v. Hodges, 135 S. Ct. 2584 (2015) (No. 14-556), 2015 WL 860738 [hereinafter Petitioners' Brief, Obergefell].

236. Id. at 3-4.

237. Id. at 3 .

238. Id.

239. Id. 
stated:

Petitioners married seeking a cherished status that protects families throughout life, from cradle to grave. But Ohio refuses to respect the dignity and status conferred on Petitioners' marriages by other states. From the start of the marriage to the birth of children to the death of one spouse and beyond, Ohio erases the legal relationships of Petitioners' families. Ohio treats these spouses as legal strangers to one another and recognizes only one member of each couple as the legal parent to their children. Ohio even cruelly refuses to recognize Petitioners' marriages on death certificates when one spouse dies. Through its marriage recognition bans, Ohio strikes out at a class of individuals whose intimate, personal relationships have been afforded a solemn and special status by other states - men and women who love and marry a person of the same sex. ${ }^{240}$

The second and third paragraphs of this three-paragraph "hello" reached the question of "why here; why now?" Notably, this emerged as the major rift between the majority and the dissent. Chief Justice Roberts even argued that it was a disservice to gays and lesbians to allow the Supreme Court essentially to take the issue out of public debate. ${ }^{241}$ The drafters of the Obergefell "hello" saw it differently. But for intervention by the Supreme Court, countless gays and lesbian-including their children-would suffer continued and perhaps irreparable harm as the matter played out in the court of public approval. ${ }^{242}$ In making this point, the "hello" again used words to conjure up images of specific individuals - including the children of same-sex couples-who would suffer in the interim ${ }^{243}$ and it solidly anchored the legal basis for a favorable ruling to the central holding of Windsor that the dignity of gays and lesbians-and their families-should not be demeaned. ${ }^{244}$ As powerfully set forth in the final paragraphs of the Obergefell "hello":

Ohio and the court below contend that legal recognition of the marriages of same-sex couples must await the day when the political majority of each state is ready to bestow equal rights on these families. They assert that the federal courts should stand aside while same-sex spouses and their children suffer daily hardships and indignities imposed by the unconstitutional refusal of states like Ohio to recognize these couples' marriages. Wait, they say, until the majority decides the time is right.

The Petitioners, their children, and many like them have waited too long already. Ohio widowers James Obergefell and David Michener ran out

240. Id. (emphasis added).

241. Obergefell, 135 S. Ct. at 2611-12 (Roberts, C.J., dissenting).

242. Id. at 2612 .

243. Id.

244. Petitioners' Brief, Obergefell, supra note 235, at 3-4. 
of time when death took their spouses. The infants born to the HenryRogers, Yorksmith, and Noe-McCracken families could not wait to arrive in this world until a majority voted that their parents' marriages would be honored. And Adopted Baby Doe could not wait for a home until a majority of Ohioans chose to recognize the marriage of his New York adoptive fathers. No more children should be demeaned by states like Ohio; no more loving spouses should die without the dignity that accompanies respect for their marriages, while the democratic process grinds its slow way towards justice. Following in the path of United States $v$. Windsor, which held that guarantees of liberty and equality prohibit the federal government from demeaning the dignity and integrity of the families of married same-sex spouses, this Court should declare the Ohio bans on marriage recognition unconstitutional. ${ }^{245}$

Justice Kennedy adopted this rationale in the majority opinion, which spoke of "urgency" and the "continuing" or "interim harm" nine times. ${ }^{246}$ Putting an immediate end to such harm justified judicial intervention. As Justice Kennedy explained:

The dynamic of our constitutional system is that individuals need not await legislative action before asserting a fundamental right. The Nation's courts are open to injured individuals who come to them to vindicate their own direct, personal stake in our basic charter. An individual can invoke a right to constitutional protection when he or she is harmed, even if the broader public disagrees and even if the legislature refuses to act. $^{247}$

In rejecting the key argument that the issue of same-sex marriage should be left open for further public discourse, Justice Kennedy referred to the Supreme Court's decision in Bowers. ${ }^{248}$ As discussed above, Justice Powell candidly admitted that he thought he had "made a mistake" in casting the fifth vote for the majority opinion that permitted states to continue to criminalize homosexual conduct. ${ }^{249}$ That "mistake" resulted in two decades of continued discrimination - including criminal prosecution — of gays and lesbians. ${ }^{250}$ As also discussed above, the Supreme Court at least subtly referenced that mistake when it overruled Bowers. ${ }^{251}$ The Court referenced that mistake again - in less subtle terms - in Obergefell. ${ }^{252}$ As Justice Kennedy compassionately put forth:

245. Id. (citation omitted).

246. Obergefell, 135 S. Ct. at 2594-95, 2600-02, 2604, 2606-07.

247. Id. at 2605.

248. Id. at 2606.

249. See Carol Nackenoff, Landmarks, Portents, or Just Curves in the Road?, 45 Tulsa L. REV. 659, 666 n.56 (2010).

250. See infra Part II.

251. See infra Part II.

252. Obergefell, 135 S. Ct. at 2606. 
This is not the first time the Court has been asked to adopt a cautious approach to recognizing and protecting fundamental rights. In Bowers, a bare majority upheld a law criminalizing same-sex intimacy. That approach might have been viewed as a cautious endorsement of the democratic process, which had only just begun to consider the rights of gays and lesbians. Yet, in effect, Bowers upheld state action that denied gays and lesbians a fundamental right and caused them pain and humiliation. As evidenced by the dissents in that case, the facts and principles necessary to a correct holding were known to the Bowers Court. That is why Lawrence held Bowers was "not correct when it was decided." Although Bowers was eventually repudiated in Lawrence, men and women were harmed in the interim, and the substantial effects of these injuries no doubt lingered long after Bowers was overruled. Dignitary wounds cannot always be healed with the stroke of a pen.

A ruling against same-sex couples would have the same effect-and, like Bowers, would be unjustified under the Fourteenth Amendment. The petitioners' stories make clear the urgency of the issue they present to the Court. ${ }^{253}$

In this author's opinion, the Supreme Court got it wrong once and they were not going to get it wrong again. If the Supreme Court ruled against same-sex marriage in the Obergefell cases - in order to allow additional public debate as had erroneously been done in Bowers - not only would same-sex couples not be permitted to marry in the four states at issue, but presumably, same-sex couples could be denied the right to marry in all of the states where the right to marry was based upon judicial decisions construing the U.S. Constitution. Just as had been seen in California, opponents of same-sex marriage likely would argue the interim marriages were invalid. ${ }^{254}$ This would have dealt a crushing and demeaning blow to millions of Americans, including the "hundreds of thousands" of children being raised by same-sex couples. ${ }^{255}$

To perhaps better make the case to the public that the ruling was morally justified, Justice Kennedy fashioned his own "hello" at the onset of the majority opinion. He spoke of the history and importance of marriage. ${ }^{256}$ Addressing a point raised in the Hollingsworth "hello," Justice Kennedy also spoke openly and eloquently about "love."257 In making his emotional appeal to the public, Justice Kennedy then told stories of three of the families in the lawsuit. ${ }^{258}$ He prefaced

253. Id. (emphasis added) (citations omitted).

254. See Strauss v. Horton, 207 P.3d 48, 119-22 (Cal. 2009), abrogated by Obergefell, 135 S. Ct. 2584.

255. Obergefell, 135 S. Ct. at 2600.

256. Id. at 2593-96.

257. See supra Part II.1.a.

258. Obergefell, $135 \mathrm{~S}$. Ct. at 2594-95. 
these stories by referencing the "urgency" involved. ${ }^{259}$ The brief presented each of these stories in much the same style and manner as had been done in the Windsor "hello." 260 This time, Justice Kennedy went into much, much more detail. The first story was that of James Obergefell and his deceased spouse, John Arthur. ${ }^{261}$ In telling this story-which largely tracked the Obergefell brief-Kennedy used that term "strangers" that the Obergefell "hello" set forth:

Petitioner James Obergefell, a plaintiff in the Ohio case, met John Arthur over two decades ago. They fell in love and started a life together, establishing a lasting, committed relation. In 2011, however, Arthur was diagnosed with amyotrophic lateral sclerosis, or ALS. This debilitating disease is progressive, with no known cure. Two years ago, Obergefell and Arthur decided to commit to one another, resolving to marry before Arthur died. To fulfill their mutual promise, they traveled from Ohio to Maryland, where same-sex marriage was legal. It was difficult for Arthur to move, and so the couple were wed inside a medical transport plane as it remained on the tarmac in Baltimore. Three months later, Arthur died. Ohio law does not permit Obergefell to be listed as the surviving spouse on Arthur's death certificate. By statute, they must remain strangers even in death, a state-imposed separation Obergefell deems "hurtful for the rest of time." He brought suit to be shown as the surviving spouse on Arthur's death certificate. ${ }^{262}$

Justice Kennedy then introduced April DeBoer and Jayne Rowse. ${ }^{263}$ Here too, Justice Kennedy's opinion largely tracked the underlying brief. ${ }^{264}$ In doing so, Justice Kennedy included many technically irrelevant facts. These facts operated to hammer-home the theme that gays and lesbians were ordinary, good people deserving of dignity and respect. ${ }^{265}$ The couple was raising three children, two with special needs. ${ }^{266}$ Absent judicial intervention, all of the couple's children were at immediate risk because Michigan refused to recognize dual parentage. ${ }^{267}$ As Justice Kennedy explained:

April DeBoer and Jayne Rowse are co-plaintiffs in the case from Michigan. They celebrated a commitment ceremony to honor their permanent relation in 2007. They both work as nurses, DeBoer in a neonatal unit and Rowse in an emergency unit. In 2009, DeBoer and Rowse fostered and then adopted a baby boy. Later that same year, they

259. Id. at 2594.

260. See Respondents' Brief, Windsor, supra note 131, at 1-3.

261. Obergefell, $135 \mathrm{~S}$. Ct. at 2594.

262. Id. at 2594-95 (emphasis added); see also Petitioners' Brief, Obergefell, supra note 235.

263. Obergefell, $135 \mathrm{~S}$. Ct. at 2595.

264. Id.; compare Petitioners' Brief, Obergefell, supra note 235.

265. Obergefell, 135 S. Ct. at 2595.

266. $I d$.

267. Id. 
welcomed another son into their family. The new baby, born prematurely and abandoned by his biological mother, required around-the-clock care. The next year, a baby girl with special needs joined their family. Michigan, however, permits only opposite-sex married couples or single individuals to adopt, so each child can have only one woman as his or her legal parent. If an emergency were to arise, schools and hospitals may treat the three children as if they had only one parent. And, were tragedy to befall either DeBoer or Rowse, the other would have no legal rights over the children she had not been permitted to adopt. This couple seeks relief from the continuing uncertainty their unmarried status creates in their lives. ${ }^{268}$

Justice Kennedy then introduced the final couple, who were a military couple. ${ }^{269}$ This raised the classic issue that involved the reconciliation of two competing deeply-held beliefs. How can we ask those in the military to risk their lives for our country while at the same time denying them equal rights? In introducing this couple, Justice Kennedy mentioned "disappearing" rights, tracking a reference in these petitioners" "hello" to a "checkerboard nation in which same-sex couples' marriages are dissolved and reestablished as they travel or move from state to state. ${ }^{270}$ In Justice Kennedy's words:

Army Reserve Sergeant First Class Ijpe DeKoe and his partner Thomas Kostura, co-plaintiffs in the Tennessee case, fell in love. In 2011, DeKoe received orders to deploy to Afghanistan. Before leaving, he and Kostura married in New York. A week later, DeKoe began his deployment, which lasted for almost a year. When he returned, the two settled in Tennessee, where DeKoe works full-time for the Army Reserve. Their lawful marriage is stripped from them whenever they reside in Tennessee, returning and disappearing as they travel across state lines. DeKoe, who served this Nation to preserve the freedom the Constitution protects, must endure a substantial burden. ${ }^{271}$

Justice Kennedy returned to these three stories just following the abovereferenced discussion of Bowers. ${ }^{272}$ The following passage exactly tracked the language in the third sentence of the Obergefell "hello" that noted Ohio eliminated the legal structure of the petitioners' families. ${ }^{273}$ It also squarely responded to the need for urgency and the demand in the Obergefell "hello" that "[n]o more children should be demeaned by states like Ohio" and "no more loving spouses should die without the dignity that accompanies respect for their

268. Id. (emphasis added).

269. Id.

270. Brief for Petitioners at 3, Tanco v. Haslam, 135 S. Ct. 2584 (2015) (No. 14-562), 2015 WL 860739 .

271. Obergefell, $135 \mathrm{~S}$. Ct. at 2595 (emphasis added).

272. Id. at 2606.

273. Petitioners' Brief, Obergefell, supra note 235, at 3. 
marriages, while the democratic process grinds its slow way towards justice."274 As Justice Kennedy passionately stated:

The petitioners' stories make clear the urgency of the issue they present to the Court. James Obergefell now asks whether Ohio can erase his marriage to John Arthur for all time. April DeBoer and Jayne Rowse now ask whether Michigan may continue to deny them the certainty and stability all mothers desire to protect their children, and for them and their children the childhood years will pass all too soon. Ijpe DeKoe and Thomas Kostura now ask whether Tennessee can deny to one who has served this Nation the basic dignity of recognizing his New York marriage. Properly presented with the petitioners' cases, the Court has a duty to address these claims and answer these questions. ${ }^{275}$

In holding that bans against same-sex marriage were unconstitutional, the Supreme Court rose to the challenge of the Obergefell "hello" and honored the many personal stories set forth in each of the briefs. ${ }^{276}$ These litigants would not have to wait for decades to receive their constitutional rights. Nor would any of the other millions of affected Americans, specifically including the "hundreds of thousands" of children being raised by same-sex couples. ${ }^{277}$

Did the Obergefell briefs - and the earlier briefs in Hollingsworth and Windsor - sway a particular justice? Although we may never know, it appears clear that the "hellos" in these cases did impact the drafting of the Supreme Court opinions. At minimum, the emotional hooks provided ammunition to make the case that the result was more than legally sound; it was just. This is far from an isolated occurrence. The impact of emotionally-charged "hellos" can be seen not only in Obergefell, but also in the other five-to-four Supreme Court decisions discussed below, specifically including Adoptive Couple v. Baby Girl. ${ }^{278}$ Here too, the focus was on family.

\section{B. Adoptive Couple v. Baby Girl: Parental Rights Under the Indian Child Welfare Act}

At a child-custody hearing, a father walks into a courtroom wearing tattered jeans, a filthy tee-shirt, and smelling like yesterday's garbage. The family law judge makes an immediate assessment. Although there might be a valid reason for his disheveled appearance, the father faces an almost insurmountable hurdle. The inner voice we all hear in our heads has already spoken. Casting a disproving glare at the father, our family law judge already said to herself: "That guy is not getting that kid."

274. Id. at 4 .

275. Obergefell, 135 S. Ct. at 2606 (emphasis added).

276. Id. at 2608 .

277. Id. at 2600 .

278. Adoptive Couple v. Baby Girl, 133 S. Ct. 2552 (2013), remanded to 746 S.E.2d 51 (S.C. 2013). 
The writers of the prevailing brief in Adoptive Couple v. Baby Girl likely knew that many judges-possibly even including our Supreme Court justices-have had a stint at family court, perhaps early in their career. If not, there is a good chance they know of a fellow judge who has and may therefore understand the need to look beyond the court filings when making a determination as to the fitness of a parent. It is one of the areas of law where society particularly wants judges to step in and exercise their discretion. A trial court judge's factual assessments on this point appear normally to be given extraordinary weight. This is because the trial court judge is afforded the opportunity to look each parent in the eye when making the determination as to that parent's fitness.

At issue in Adoptive Couple was whether a non-custodial parent, more particularly, an unwed father, was entitled to certain rights under the Indian Child Welfare Act ("ICWA"). ${ }^{279}$ The biological parents of "Baby Girl" were in a relationship, but broke up prior to Baby Girl's birth. ${ }^{280}$ The birth mother-who was not Native American-gave up Baby Girl at birth for adoption to a couple that also was not Native American. ${ }^{281}$ The biological father, a Native American, along with the Cherokee Nation, fought the adoption. ${ }^{282}$ There were three statutory provisions in the ICWA that appeared to recognize the right of the biological father to be awarded custody. ${ }^{283}$ The Birth Father prevailed at both the trial court and appellate levels. ${ }^{284}$ The case involved straightforward statutory construction pertaining to congressional intent and the rights of unwed biological fathers. ${ }^{285}$

Given the emotional stakes, the attorneys drafting the brief for the petitioners employed the classic technique of choosing a particularly inflammatory fact and making that fact the reader's first — and lasting — impression of the case. ${ }^{286}$ The "hello" hit hard and fast. The first words at the starting block were that the birth father had renounced his parental rights in a text message and that he had made no efforts to see his child for months after she had been born. ${ }^{287}$ As simply stated:

After unceremoniously renouncing his parental rights to his unborn daughter-Baby Girl-in a text message and making no effort to see Baby Girl for months after she was born, Father stepped in at the eleventh hour to block an adoption that was lawful and in the "best

279. Id. at $2556-58$.

280. Id. at 2558 .

281. Id.

282. Id. at 2558-59.

283. Id. at $2557-58$.

284. Id. at 2559 .

285. Id.

286. Brief for Petitioners, Adoptive Couple v. Baby Girl, 133 S. Ct. 2552 (2013) (No.12-399), 2013 WL 633597 [hereinafter Petitioners' Brief, Adoptive Couple].

287. Id. at 1 . 
interests" of Baby Girl. ${ }^{288}$

There was no need to tell the reader the birth-father was a dead-beat dad. The facts spoke for themselves. The "hello" continued its emotional attack including use of a powerful visual image capturing heartache flowing from the lower court's order:

Father claimed the authority to break up the adoptive family because Baby Girl is a "biological child of a member of an Indian tribe" and is herself eligible for membership. The state courts determined that state law and the best interests of Baby Girl must yield to federal law, and by command of court order Baby Girl was taken from petitioners after the family had been together for over two years. The overriding question in this case is whether Congress intended that result. It did not and could not have. ${ }^{289}$

The final two paragraphs of the "hello" were equally powerful, again contrasting the image of a dead-beat dad against the image of a vulnerable baby girl snatched from the arms of two loving parents:

We do not doubt that some fathers who initially renounce a desire to be a parent may sincerely have a change of heart about parenthood upon learning of a mother's adoptive placement. But our society has long barred unwed fathers from joining the game of child-rearing too late. The law limits the window of opportunity for unwed fathers to embrace parenthood to protect a child's paramount interest in forming immediate and stable family bonds. The necessity of prompt decision-making comes even earlier for unwed pregnant mothers. ICW A does not upset these principles and does not permit the unwed father who acts too late under state law to veto the mother's adoptive placement.

We also assume that the Tribe here is sincere in believing that any child with any amount of Indian blood should be raised in an Indian home. But ICW A struck quite a different balance that does not countenance the chaos and heartbreak that would ensue if tribes or noncustodial fathers with no right to object to an adoption could later uproot Indian children from their adoptive families. ICW A does not, as respondents contend and the court below held, impose a Kafkaesque exercise requiring mothers and prospective adoptive parents to endeavor to "rehabilitate" absentee fathers and also go in search of an Indian family to raise the child. ${ }^{290}$

The petitioners' "hello" easily invited a careful read of the statement of facts. Could all of this really be true? Per the petitioners, the answer was "yes," and then some. The statement of facts was packed with more inflammatory

288. $I d$.

289. Id. at 1-2 (emphasis added).

290. Id. at 4 (emphasis added). 
facts - largely irrelevant to the legal issues - including the following seemingly innocuous fact regarding the percentage of Baby Girl's ancestry. ${ }^{291}$ In a footnote, the petitioners pointed out: "Our reply brief at the petition stage stated that Baby Girl is 1/16 Cherokee. We have since reviewed records from Baby Girl's paternal grandparents reflecting that Baby girl [sic] is 3/256 Cherokee." 292

Did this seemingly innocuous - and wholly irrelevant-fact make it into the Supreme Court's opinion? The answer is yes, front-and-center, and then again when Justice Alito began the legal analysis. ${ }^{293}$ The Supreme Court would even do the math. Also front-and-center was the theme of "dead-beat dad" versus loving adoptive parents. Here is the very first passage of the Supreme Court's opinion, which Justice Alito wrote:

This case is about a little girl (Baby Girl) who is classified as an Indian because she is $1.2 \%(3 / 256)$ Cherokee. Because Baby Girl is classified in this way, the South Carolina Supreme Court held that certain provisions of the federal Indian Child Welfare Act of 1978 required her to be taken, at the age of 27 months, from the only parents she had ever known and handed over to her biological father, who had attempted to relinquish his parental rights and who had no prior contact with the child. The provisions of the federal statute at issue here do not demand this result. ${ }^{294}$

The majority opinion further adopted the words and tenor of both the petitioners" "hello"-including that text message-and the continued character assault in the statement of facts. ${ }^{295}$ As set forth in the petitioners' brief:

Baby Girl's biological parents- "Mother" and "Father"-self-identify respectively as Hispanic and Indian. They became engaged to be married in December 2008. Father was then serving in the military and was stationed at Fort Sill, Oklahoma, while Mother lived four hours away in Bartlesville, Oklahoma. One month after the [couple became] engage [d], Mother informed Father in January 2009 that she was pregnant. Mother asked him to assist with medical expenses before the first doctor's visit in February; Father refused. He withheld any financial support throughout the pregnancy, stating that he would offer support only if he and Mother were married. He pressed Mother to quit her job, move to

291. Id. at 6 .

292. Id. at 6 n.1.

293. Adoptive Couple v. Baby Girl, 133 S. Ct. 2552, 2556, 2559 (2013), remanded to 746 S.E.2d 51 (S.C. 2013).

294. Id. at 2556-57 (emphasis added). Note also that the ending sentences of the majority opinion track the ending sentences of the first paragraph of the petitioners" "hello": "The overriding question in this case is whether Congress intended that result. It did not and could not have." Compare Petitioners' Brief, Adoptive Couple, supra note 286, at 2, with Adoptive Couple, 133 S. Ct. at 2565.

295. Adoptive Couple, 133 S. Ct. at 2556-57. 
the military base with her two other children, and marry him immediately so that his military pay would increase. When Mother demurred, the couple's relationship deteriorated, and Mother broke off the engagement in May 2009. ${ }^{296}$

As the emphasized text below shows, this passage is strikingly similar to the wording in the majority opinion. In the words of Justice Alito:

In this case, Birth Mother (who is predominantly Hispanic) and Biological Father (who is a member of the Cherokee Nation) became engaged in December 2008. One month later, Birth Mother informed Biological Father, who lived about four hours away, that she was pregnant. After learning of the pregnancy, Biological Father asked Birth Mother to move up the date of the wedding. He also refused to provide any financial support until after the two had married. The couple's relationship deteriorated, and Birth Mother broke off the engagement in May 2009. In June, Birth Mother sent Biological Father a text message asking if he would rather pay child support or relinquish his parental rights. Biological Father responded via text message that he relinquished his rights. ${ }^{297}$

Interestingly, the majority opinion failed to include one key fact that that even the petitioners frankly admitted in their brief. Birth Father was an American soldier. ${ }^{298}$ Although he lived "about four hours away," that was only because he was stationed at the Fort Sill military base. ${ }^{299}$ Also, Birth Father's brief included - but found nowhere in the majority opinion - a further explanation as to the lack of communication between the couple. ${ }^{300}$ That explanation was simple. Birth Mother refused to answer either his phone calls or texts or even see him when he made the four-hour trip from Fort Sill to do just that. ${ }^{301}$

Instead of championing Birth Father's military service-a technique employed in Obergefell ${ }^{302}$ - the majority opinion incorporated the petitioners' compassionate story of the pregnancy and Baby Girl's birth. ${ }^{303}$ In the petitioners' words:

Adoptive Parents supported Mother financially and emotionally during her pregnancy and shortly after Baby Girl's birth. They spoke to Mother

296. Petitioners' Brief, Adoptive Couple, supra note 286, at 6 (emphasis added) (citations omitted).

297. Adoptive Couple, 133 S. Ct. at 2558 (emphasis added).

298. Petitioners' Brief, Adoptive Couple, supra note 286, at 2.

299. Id. at 6.

300. Brief in Opposition at 5, Adoptive Couple v. Baby Girl, 133 S. Ct. 2552 (2013) (No.12399), 2012 WL 5994979 [hereinafter Respondents' Brief, Adoptive Couple].

301. Id. at 5-7.

302. See Obergefell v. Hodges, 135 S. Ct. 2584, 2595 (2015).

303. Adoptive Couple v. Baby Girl, 133 S. Ct. 2552, 2558 (2013), remanded to 746 S.E.2d 51 (S.C. 2013). 
weekly, and Adoptive Mother traveled to visit her in Oklahoma in August 2009. They paid for medical expenses associated with the pregnancy.

Baby Girl was born on XX/XX/2009. Adoptive Parents were in the delivery room during the delivery, and Adoptive Father cut the umbilical cord. The next morning, Mother placed Baby Girl with Adoptive Parents and signed forms consenting to the adoption. ${ }^{304}$

As the majority opinion set forth:

Adoptive Couple supported Birth Mother both emotionally and financially throughout her pregnancy. Adoptive Couple was present at Baby Girl's birth in Oklahoma on September 15, 2009, and Adoptive Father even cut the umbilical cord. The next morning, Birth Mother signed forms relinquishing her parental rights and consenting to the adoption. ${ }^{305}$

The final words of the factual background in the majority opinion conjured up those powerful images set forth in the petitioners' "hello" of a loving Baby Girl pried from the arms of her loving adoptive parents. As Justice Alito stated: "On December 31, 2011, at the age of 27 months, Baby Girl was handed over to Biological Father, whom she had never met." 306

By this author's count, the majority opinion hammered-home the "dead-beat dad" versus loving adoptive couple theme eleven times. ${ }^{307}$ Although this was tame compared to the whopping thirty-nine times the petitioners' used this theme in their brief, ${ }^{308}$ it still is powerful evidence that the Supreme Court will use the facts and emotional appeals advanced by the litigants in order to make its case that the end result is morally justified. In the words of the hypothetical family law judge referred to in the opening paragraph of this section: "That guy was not

304. Petitioners' Brief, Adoptive Couple, supra note 286, at 9 (emphasis added).

305. Adoptive Couple, 133 S. Ct. at 2558.

306. Id. at 2559 (emphasis added).

307. These references can be found at $i d$. at 2556-58, 2562-63. Birth Father was often characterized as having "abandoned" Baby Girl. See id. at 2562-63. This is not exactly supported by the record. Birth Mother gave up Baby Girl the day she was born and the adoptive couple moved Baby Girl out-of-state to South Carolina within a few days. Id. at 2558. As noted above, Birth Mother previously refused to accept Birth Father's calls or to see him when he made the four-hour trip from Fort Sills to see her. See Respondents' Brief, Adoptive Couple, supra note 300, at 5-7. The majority opinion faulted Birth Father for never formally seeking to "adopt" Baby Girl, as opposed to opposing the adoption by arguing that his "parental rights should not [have been] terminated in the first place." Adoptive Couple, 133 S. Ct. at 2564. For this reason, the majority held that Section 1915(a) was inapplicable. Id. That section gave a statutory preference to "(1) a member of the child's extended family; (2) other members of the Indian child's tribe; or (3) other Indian families." Id. (quoting 25 U.S.C. $§ 1915$ (2012)).

308. These references can be found at Petitioners' Brief, Adoptive Couple, supra note 286, at 1-4, 6-7, 9-11, 13, 18, 20, 26-28, 31, 41, 46, 48, 53, 56. Petitioners' brief was fifty-seven pages. 
getting that kid."

The dissent did not miss this point. Justice Sotomayor, joined by Justices Ginsburg, Kagan and Scalia, called out the majority for its "focus on the perceived parental shortcomings of Birth Father." ${ }^{\circ 09}$ This certainly suggested that the dissenters believed that emotions had gotten in the way of reason in the majority opinion.

Notably, this five-to-four decision may have been razor close. Justice Breyer's concurring opinion raised concerns about the broader implications in order to narrow the applicability of the Supreme Court decision. ${ }^{310}$ Still, it unmistakably placed unwed Native-American fathers on much different footing than their married counterparts. ${ }^{311}$ Ironically, this was in a case where the birthfather wanted nothing more than to marry the birth mother and raise their daughter in a Native American home. ${ }^{312}$

No doubt the attorneys for Birth Father took what they likely believed to be the high-road. Many would say that rank emotional appeals have no business being in a Supreme Court brief. ${ }^{313}$ From this author's perspective, the "hello" nicely laid out the congressional intent behind the ICW A. ${ }^{314}$ The first paragraph of the "Statutory Background" section made clear that Congress passed the ICW A to curb a "crisis" whereby Native-American children were being raised in adoptive or foster homes at a grossly disproportionate rate-eight times the national average - and $90 \%$ of these placements were with non-Native American parents. $^{315}$

The brief also methodically marched through sound legal arguments as to why Birth Father should prevail. ${ }^{316}$ The final paragraph of the "hello" also took at least one swing at the petitioners' inflammatory rhetoric by countering that Birth Father sought to assert his rights the moment he was informed of the adoption. ${ }^{317}$ This paragraph also pointed out that at least someone-the family court judge- thought Birth Father was a deserving and fit parent. ${ }^{318}$

Yet there was an emotional card that the attorneys for Birth Father could have played a bit more. From the get-go, the petitioners painted the emotional image of Baby Girl being taken from their arms at twenty-seven months, having never even met her birth-father. ${ }^{319}$ Yet an adverse decision from the Supreme Court

309. Adoptive Couple, 133 S. Ct. at 2573 (Sotomayor, J., dissenting). Justice Sotomayor also noted that a "[p]olicy disagreement with Congress' judgment is not a valid reason for this Court to distort the provisions of the Act." Id. at 2572.

310. Id. at 2571 (Breyer, J., concurring).

311. Id.

312. Respondents' Brief, Adoptive Couple, supra note 286, at 6-8.

313. See supra Part I.C.

314. Respondents' Brief, Adoptive Couple, supra note 286, at 1.

315. Id. at $1-2$.

316. See, e.g., id. at 2-5.

317. Id. at 2 .

318. Id.

319. Id. 
would give rise to another heart-wrenching ordeal. After living and bonding with her Birth Father for well over a year, Baby Girl—now almost 4 years old-would be wrested from the arms of her Birth Father and handed over to a non-Native American couple, of whom she likely had little or no memory. ${ }^{320}$ Should any child endure two such emotional ordeals in such a short time? Was this really the intent of Congress when it enacted the ICW A to curb the "crisis" of so many Native American children being raised in non-Native American homes? ${ }^{321}$

Is it possible that one or more of the majority simply could not get past the petitioners' powerful "hello," specifically including that text message and the hammered-home dead-beat dad versus loving adoptive parents theme? As noted above, Justices Sotomayor certainly thought so. The lesson for practitioners? Make sure you match your opponent's emotional punch and make sure you do so at your "hello."

\section{AT\&T Mobility v. Concepcion: Preemption/Unconscionability of Class-Wide Arbitration Waivers}

In the two cases discussed above, it is fairly clear that emotional appeals played a powerful role in both the briefing and the Supreme Court opinion. A skeptic might argue that this is simply because of the emotionally-charged nature of the cases. Balderdash! Emotional appeals are made by top law firms in run-ofthe-mill contract cases. These emotional appeals-even if they have nothing to do with the merits of the case-still are prominently featured in the resulting Supreme Court opinion.

In $A T \& T$ v. Concepcion, attorneys representing AT\&T faced the daunting task of arguing the Federal Arbitration Act ("FAA") preempted use of California case law to invalidate a clause in an AT\&T consumer agreement that prohibited class action arbitrations. ${ }^{322}$ In other words, the agreements required consumers to arbitrate and they only could do so in their individual capacity. ${ }^{323}$ The hurdle facing the AT\&T attorneys was that the FAA contained a savings clause that permitted courts to invalidate arbitration agreements based upon "generally

320. Justice Sotomayor raised this point in the last substantive paragraph of her dissent. Adoptive Couple v. Baby Girl, 133 S. Ct. 2552, 2586 (2013), remanded to 746 S.E.2d 51 (S.C. 2013) (Sotomayor, J., dissenting.). The scene is reminiscent of the "Baby Richard" case discussed in Anthony S. Zito, Baby Richard and Beyond: The Future for Adopted Children, 18 N. ILL. U. L. REV. 445 (1998). As poignantly described by Zito:

On April 30, 1995, the Baby Richard case came to a much anticipated end when Otakar Kirchner, accompanied by his wife and attorneys, arrived at 'Baby Richard's' home.

Pulling him from his adoptive mother's arms and carrying him into an awaiting minivan, Baby Richard was taken by his biological parents to begin another life.

Id. at 445 .

321. Adoptive Couple, 133 S. Ct. at 2557.

322. AT\&T Mobility, LLC v. Concepcion, 131 S. Ct. 1740, 1744 (2011), remanded to 663 F.3d. 1034 (9th Cir. 2011).

323. Id. at 1746 . 
applicable" state laws. ${ }^{324}$ California had just that; California Civil Code section 1670.5 permitted courts to prohibit enforcement of any contract deemed "unconscionable." "325

AT\&T lost at both the district and circuit court levels, but it managed to leave with what proved to be a very nice bone. ${ }^{326}$ Although bound by clear California precedent mandating a finding that arbitration agreements that prohibited claims to be brought on a class-wide basis were unconscionable, the district court judge characterized the agreement as containing "perhaps the most fair and consumerfriendly provisions this Court has ever seen." 327 Of course, the perceived fairness had nothing at all to do with preemption. But it had everything to do with our fundamental notion of justice.

The quote from the district court judge was the first words off the starting block in AT\&T's winning Supreme Court brief. ${ }^{328}$ Also highlighted was the possibility that the claimant could potentially walk away with " $\$ 7500$ " and "double attorneys' fees" if a court awarded them more than AT\&T's last settlement offer. ${ }^{329}$ As set forth below, both of these notions would permeate the Supreme Court opinion, another 5-4 close decision that would have an extraordinary impact on consumer law. The first paragraph of AT\&T's short but powerful three-paragraph "hello" stated:

The arbitration agreement in the wireless service contract between respondents Vincent and Liza Concepcion and AT\&T Mobility LLC ("ATTM") contains, in the words of one federal district judge, "perhaps the most fair and consumer-friendly provisions this Court has ever seen." Among other things, the arbitration agreement specifies that the Concepcions may arbitrate for free and are entitled to a minimum recovery of $\$ 7,500$, plus double attorneys' fees, if the arbitrator awards them more than ATTM's last settlement offer. ${ }^{330}$

324. Id. at $1744-46$.

325. CAL. Civ. CODE $\S 1670.5$ (2015).

326. Concepcion, 131 S. Ct. 1745.

327. Brief for Petitioner at 1, AT\&T Mobility v. Concepcion, 131 S. Ct. 1740 (2011) (No. 09893), 2010 WL 3017755 (quoting Makarowski v. AT\&T Mobility, LLC, No. CV 09-1590-GAF (CWx), 2009 WL 1765661, at*3 (C.D. Cal. June 18, 2009)) [hereinafter Petitioners' Brief, Concepcion].

328. Id.

329. Id.

330. Concepcion recently was heavily cited in DirectTV, Inc. v. Imburgia, No. 14-462 (U.S. Dec. 14, 2015). Justice Breyer wrote the majority opinion, which affirmed use of bans on class actions in arbitration agreements. Id. At issue was the meaning of a 2007 arbitration agreement (pre-dating Concepcion) that provided that the entire arbitration provision was nullified if the classwide ban was unenforceable under the law of a consumer's state. $I d$. at *3. The majority opinion found the answer was controlled by Concepcion and emphasized the need to follow Concepcion despite the fact that it was a "closely divided" 5-4 decision. Id. at 5. The opening paragraph of Justice Ginsburg's dissent acknowledged the precedential effect, but stated that Justice Ginsburg 
Of course, as the dissent would point out, the promise of $\$ 7500$ and double attorney fees was a bit hollow. ${ }^{331}$ The dollar amount at issue in Concepcion was $\$ 30.22 .^{332}$ In Justice Breyer's words: "What rational lawyer would have signed on to represent the Concepcions ... for the possibility of fees stemming from a $\$ 30.22$ claim?" ${ }^{333}$ It certainly also could be assumed that AT\&T could easily avoid ever paying the $\$ 7500$ by simply offering to settle any claim that was remotely meritorious on the eve of arbitration. ${ }^{334}$ But it sure sounded good. So good that reference to these two provisions would ultimately make it into the majority opinion a total of three times. ${ }^{335}$

The second and third paragraphs of AT\&T's "hello" continued to hammerhome the perceived "consumer-friendly" nature of the agreement. ${ }^{336}$ In all, there would be forty-one references either to the trial court or the Ninth Circuit's favorable assessment of the contract provisions, a full five being found in AT\& T's three-paragraph "hello." 337 The "hello" ended with a traditional "parade of horribles" paired with a reprise of the "consumer-friendly" quote from the district judge:

The district court in this case found that the arbitration provision "sufficiently incentivizes consumers" to pursue "small dollar" claims and "prompts ATTM" to make generous settlement offers "even for claims of questionable merit." The Ninth Circuit agreed that the incentives created by this provision "essentially guaranteed" that ATTM would make whole any customer who submits a claim. Nonetheless, both courts felt "compel[led]" to hold that ATTM's arbitration provision is unconscionable under California law-not because it is unfair to the named plaintiffs or would prevent them from vindicating their own claims-but because it would prevent them from representing a putative class of ATTM subscribers with allegedly similar state-law claims.

If allowed to stand, the Ninth Circuit's decision applying California law will be the death knell for consumer arbitration in California, and

would "take no further step to disarm consumers, leaving them without effect access to justice." Id. at *9 (Ginsburg, J., dissenting).

331. Concepcion, 131 S. Ct. at 1760 (Breyer, J., dissenting).

332. Id. at 1744 .

333. Id. at 1761 .

334. Id. at 1760-61. As Justice Breyer put in his dissent (joined by Justices Ginsburg, Sotomayor, and Kagan), “AT\&T can avoid the $\$ 7,500$ payout (the payout that supposedly makes the Concepcions' arbitration worthwhile) simply by paying the claim's face value, such that 'the maximum gain to a customer for the hassle of arbitrating a $\$ 30.22$ dispute is still just $\$ 30.22$." ' $I d$. at 1760 .

335. These references can be found at Concepcion, 131 S. Ct. at 1744-45, 1753.

336. Petitioners' Brief, Concepcion, supra note 327, at 2-3.

337. These references can be found at $i d$. at 1-2, 10-13, 29, 33-34, 35, 35 n.11, 36, 38, 42. AT\&T's brief was fifty-seven pages. 
possibly in many other States within that Circuit. For if an arbitration agreement that contains "perhaps the most fair and consumer-friendly provisions" that one judge has ever seen is unenforceable under California law, then no agreement providing for bilateral arbitration will be enforceable under California law. As we explain, however, the Ninth Circuit's decision cannot stand. The California rule applied by the Ninth Circuit is preempted by the Federal Arbitration Act ("FAA"). ${ }^{338}$

AT\&T's brief quickly followed through on the promise of its "hello" by providing a bullet-point laundry list of all of "consumer-friendly" terms that drew so much praise from the district and appellate courts. ${ }^{339}$ This four-page laundry list was in addition to the forty-one express references noted above to the perceived fairness of the agreement by the trial court and Ninth Circuit. ${ }^{340}$ As set forth in AT\&T's brief in pertinent part:

The arbitration provision affords customers fair, inexpensive, and convenient procedures and, in addition, provides them with affirmative incentives to pursue even small claims on an individual basis.

The procedural safeguards include:

- Cost-free arbitration for non-frivolous claims: "[ATTM] will pay all [American Arbitration Association ("AAA")] filing, administration and arbitrator fees" unless the arbitrator determines that the claim "is frivolous or brought for an improper purpose (as measured by the standards set forth in Federal Rule of Civil Procedure 11(b))";

- Convenience: Arbitration takes place "in the county *** of [the customer's] billing address," and for claims of $\$ 10,000$ or less, customers have the exclusive right to choose whether the arbitrator will conduct an in-person hearing, a hearing by telephone, or a "desk" arbitration in which "the arbitration will be conducted solely on the basis of documents submitted to the arbitrator" ...

- Small claims court option: Either party may bring a claim in small claims court in lieu of arbitration;

- Full remedies available: The arbitrator may award the claimant any form of individual relief (including statutory attorneys' fees, statutory damages, punitive damages, and injunctions) that a court could award; and ...

The features that are designed to encourage consumers to pursue claims

338. Id. at $1-2$.

339. Petitioners' Brief, Concepcion, supra note 327 , at 5-8.

340. See supra note 337. 
through bilateral arbitration include:

- \$7,500 minimum recovery if arbitral award exceeds ATTM's last settlement offer: If the arbitrator awards a California customer relief that is greater than ATTM's last "written settlement offer made before an arbitrator was selected" but less than $\$ 7,500$, ATTM will pay the customer \$7,500 rather than the smaller arbitral award;

- Double attorneys'fees: If the arbitrator awards the customer more than ATTM's last written settlement offer, then ATTM will "pay [the customer's] attorney, if any, twice the amount of attorneys' fees, and reimburse any expenses, that [the] attorney reasonably accrues for investigating, preparing, and pursuing [the] claim in arbitration"; and

- ATTM disclaims right to seek attorneys' fees: “Although under some laws [ATTM] may have a right to an award of attorneys' fees and expenses if it prevails in an arbitration, [ATTM] agrees that it will not seek such an award [from the customer]."

Moreover, ATTM has made its arbitration procedures easy to use. $A$ customer need only fill out and mail a one-page Notice of Dispute form that ATTM has posted on its web site. ATTM's legal department generally responds to a notice of dispute with a written settlement offer. If the dispute is not resolved within 30 days, the customer may invoke the arbitration process by filling out a one-age Demand for Arbitration form (also available on ATTM's web site) .... ${ }^{341}$

Crazy California! How could a court possibly find unconscionable the "most fair

341. Id. at 5-8. In footnote two, AT\&T shed more light into a provision that perhaps was not so consumer friendly. As noted, above, consumers can be held liable for the arbitration costs if the arbitrator finds that a claim was "frivolous or brought for an improper purpose." Id. at 5. Footnote two noted that the AAA's consumer arbitration rules would "cap a consumer's arbitration costs at \$125." Id. at 57 n.2. Still, assuming AT\&T's customer service department already told the consumer numerous times that his or her claim has no merit (i.e., frivolous), this could easily chill consumers from pursuing a claim. As Justice Breyer noted in his dissent, "agreements that forbid the consolidation of claims can lead small-dollar claimants to abandon their claims rather than to litigate." AT\&T Mobility, LLC v. Concepcion, 131 S. Ct. 1740, 1760 (2011), remanded to 663 F.3d. 1034 (9th Cir. 2011) (Breyer, J., dissenting). This especially is so when the small dollar amount of a claim - like $\$ 30.22$ - is outweighed by the burdens imposed, such as when a claimant has to "fill[] out many forms that require technical legal knowledge" or when a claimant is stymied by "waiting at great length while a call is placed on hold." Id. at 1761. Put simply, it is bad enough to be cheated out of $\$ 30.22$ by a wireless provider. It would add insult to injury to have to pay that carrier an additional $\$ 125$ after likely expending hours of time submitting the claim and going through arbitration. 
and consumer-friendly provisions" ever seen $?^{342}$

Justice Scalia delivered the majority opinion. ${ }^{343}$ Although he did not follow AT\&T's lead and open with the "consumer-friendly" quote from the district court judge, the third paragraph of the opinion launched into the first of many references to the perceived fairness of the arbitration clause. ${ }^{344}$ In large part, Justice Scalia tracked - often verbatim - that long-bullet point list of all of the "consumer friendly" provisions set forth in AT\& T's brief, specifically including reference to that $\$ 7500$ and double-attorneys' fee clause. In its entirety, the third paragraph of the majority opinion stated:

The revised agreement provides that customers may initiate dispute proceedings by completing a one-page Notice of Dispute form available on AT\&T's Web site. AT\&T may then offer to settle the claim; if it does not, or if the dispute is not resolved within 30 days, the customer may invoke arbitration by filing a separate Demand for Arbitration, also available on $A T \& T$ 's Web site. In the event the parties proceed to arbitration, the agreement specifies that $A T \& T$ must pay all costs for nonfrivolous claims; that arbitration must take place in the county in which the customer is billed; that, for claims of $\$ 10,000$ or less, the customer may choose whether the arbitration proceeds in person, by telephone, or based only on submissions; that either party may bring a claim in small claims court in lieu of arbitration; and that the arbitrator may award any form of individual relief, including injunctions and presumably punitive damages. The agreement, moreover, denies AT\&T any ability to seek reimbursement of its attorney's fees, and, in the event that a customer receives an arbitration award greater than $A T \& T$ 's last written settlement offer, requires $A T \& T$ to pay a $\$ 7,500$ minimum recovery and twice the amount of the claimant's attorney's fees. ${ }^{345}$

An omitted footnote at the very end of this passage in the majority opinion noted that the "guaranteed minimum recovery was increased in 2009 to $\$ 10,000 .{ }^{\$ 346}$ Of course, this fact is wholly irrelevant to the legal issue-and even irrelevant to the factual issues before the Court-but it was highly relevant to the theme of portraying AT\&T in a positive light. Where did that footnote come from? As AT\&T's brief set forth in footnote three:

Under the 2006 provision, the amount of the minimum payment is tied to the jurisdictional maximum of the customer's local small claims court. In California, the jurisdictional limit for small claims court is $\$ 7,500$. In 2009, ATTM revised this aspect of its arbitration provision to make the

342. Petitioners' Brief, Concepcion, supra note 327, at 1.

343. Concepcion, 131 S. Ct. at 1743 (majority opinion).

344. Id. at 1744 .

345. Id. (emphasis added).

346. Id. at 1744 n.3. 
minimum payment a uniform amount-\$10,000-across the country. ${ }^{347}$

Justice Scalia waited until just the fifth paragraph to refer to the trial court judge's opinion of the fairness of the arbitration agreement. ${ }^{348}$ This paragraph also included yet another reference to the $\$ 7500$ clause. ${ }^{349}$ This time, Justice Scalia even characterized it as a "premium." 350 As Justice Scalia presented:

[The District Court] described AT\&T's arbitration agreement favorably, noting, for example, that the informal dispute-resolution process was "quick, easy to use" and likely to "promp[t] full or . . even excess payment to the customer without the need to arbitrate or litigate"; that the $\$ 7,500$ premium functioned as "a substantial inducement for the consumer to pursue the claim in arbitration" if a dispute was not resolved informally; and that consumers who were members of a class would likely be worse off. ${ }^{351}$

The $\$ 7500$ clause made one more appearance in the curtain call of Justice Scalia's majority opinion. Again, the majority paired it with the favorable opinions of both the district court judge and the Ninth Circuit. ${ }^{352}$ In the last substantive paragraph, Justice Scalia concluded:

As noted earlier, the arbitration agreement provides that AT\&T will pay claimants a minimum of $\$ 7,500$ and twice their attorney's fees if they obtain an arbitration award greater than AT\&T's last settlement offer. The District Court found this scheme sufficient to provide incentive for the individual prosecution of meritorious claims that are not immediately settled, and the Ninth Circuit admitted that aggrieved customers who filed claims would be "essentially guarantee[d]" to be made whole. Indeed, the District Court concluded that the Concepcions were better off under their arbitration agreement with $A T \& T$ than they would have been as participants in a class action, which "could take months, if not years, and which may merely yield an opportunity to submit a claim for recovery of a small percentage of a few dollars." 353

This case would seem to support the argument strongly that the Supreme Court wishes for its decisions to be perceived not only as legally sound but also fair-minded. The briefing - and the majority opinion-cast AT\&T not as the prototypical villainous big-money corporation, but rather as a badgered dogooder, victimized by the unjustified tyranny of the California courts. ${ }^{354}$ This

347. Petitioners' Brief, Concepcion, supra note 327, at 7 n.3 (emphasis added).

348. Concepcion, $131 \mathrm{~S}$. Ct. at 1745.

349. Id.

350. $I d$.

351. Id. (emphasis added) (citations omitted).

352. Id. at 1753 .

353. Id. (emphasis added).

354. Petitioners' Brief, Concepcion, supra note 327, at 12. 
technique is often referred to as "humanizing the corporation." 355 The briefing was brilliant given the California courts were merely seeking to protect consumers by ensuring they had some realistic means to redress being cheated of small-dollar amount by large corporations. As discussed below, Court nicely used the technique of humanizing the corporation not only in Concepcion, but also in Hobby Lobby.

D. Burwell v. Hobby Lobby Stores, Inc.: Religious Freedom/Abortion Rights

Hobby Lobby pitted the Religious Freedom Restoration Act of 1993 ("RFRA") against abortion rights. ${ }^{356}$ The legal issue was whether the RFRA mandated an exemption for a corporation's duty under the Affordable Care Act ("ACA") to provide health-insurance coverage for certain contraception methods that affect already-fertilized eggs, such as the "morning-after" pill. ${ }^{357}$ There were four such contraceptive methods at issue, which the Supreme Court labeled in its opinion as "abortifacients." Lobby Stores, Inc. - the main petitioner in the lead case-and Conestoga Wood Specialties Corporation ("Conestoga") — the respondent in a companion case, Conestoga Wood Specialties Corp. v. Sebelius. ${ }^{359}$

Even pro-choice advocates would struggle with the idea of legally forcing a pro-life advocate actually to perform an abortion or hand out abortion-inducing medication. And that essentially was exactly how the legal issue was framed. The briefing made clear that the human beings behind the corporation believed that if they provided health insurance to commit what they perceived as a sin-use of abortion-inducing mediations - that they would be complicit in that $\sin .^{360} \mathrm{In}$ other words, they would be engaging in the sinful act themselves.

Hobby Lobby's prevailing brief began with a powerful two-paragraph "hello" that immediately articulated a common-sense legal argument as to why Hobby Lobby was entitled to an exemption. ${ }^{361}$ The government already had in place an exemption scheme for non-profit entities. ${ }^{362}$ What possible reason could there be for not extending this to Hobby Lobby? Failing to do so certainly could not be the

355. See, e.g., Kimberly A. Moore, Populism and Patents, 82 N.Y.U. L. REV. 69, 111 n.96 (2007) (noting the importance of "humanizing the corporation" at jury trials).

356. See generally Burwell v. Hobby Lobby Stores, Inc., 134 S. Ct. 2751 (2014).

357. Id. at $2759,2765$.

358. Id. at 2759 .

359. Id. at 2751. The Court consolidated Conestoga Wood Specialties Corp. with Hobby Lobby. Id. at 2759.

360. See, e.g., Brief of 67 Catholic Theologians and Ethicists as Amici Curiae in Support of Hobby Lobby Stores, Inc., and Conestoga Wood Specialties Corp. at 7, 8, Burwell v. Hobby Lobby Stores, Inc., 134 S. Ct. 2751 (2014) (No. 13-354), 2014 WL 316716.

361. Brief for Respondent at 1-2, Burwell v. Hobby Lobby Stores, Inc., 134 S. Ct. 2751 (2014) (No. 13-354), 2014 WL 546899 [hereinafter Respondents' Brief, Hobby Lobby].

362. Id. at 10. 
"least restrictive" means for accomplishing the government's goals. ${ }^{363}$ The second paragraph then immediately painted the picture that it takes human beings to run a corporation. ${ }^{364}$ Those human beings-just as corporations they run-engage in religious exercise and are thereby entitled to the protections of the RFRA. ${ }^{365}$ As powerfully and crisply stated:

On the merits, this is one of the most straight-forward violations of the Religious Freedom Restoration Act this Court is likely to see. Respondents' religious beliefs prohibit them from providing health coverage for contraceptive drugs and devices that end human life after conception. Yet, the government mandate at issue here compels them to do just that, or face crippling fines, private lawsuits, and government enforcement. That is a textbook "substantial burden" on religious exercise under RFRA. Indeed, the government has effectively acknowledged this substantial burden by exempting countless non-profit entities with the same basic religious objection. And it has exempted plans covering tens of millions of people for reasons no more compelling than administrative convenience. Given these myriad exemptions, the mandate cannot possibly be the least restrictive means of achieving any compelling government interest - and it is certainly not some universal policy that cannot tolerate additional exemptions. If RFRA means anything, it means the government cannot hand out exceptions for secular reasons and then insist that "uniformity" forecloses similar exceptions for religious exercise. But the mandate does precisely that.

Understandably eager to avoid the merits, the government directs considerable effort to driving an artificial wedge between the corporate Respondents and their owners. But that distinction is illusory; both the corporations and their owners are entitled to relief under RFRA. Corporations frequently engage in religious exercise, as even the government concedes in the case of non-profits, and no constitutional right turns on a corporation's tax status. Ultimately, whether it is the individuals, the corporations, or both who are exercising religion, the government cannot simply wish away the reality that its policies substantially burden Respondents' religious exercise in a wholly unjustified manner. ${ }^{366}$

The Conestoga brief echoed this "hello":

Because citizens exercise religion in every area of their lives, this Court has recognized that individuals may exercise religion in business and that citizens may join together to exercise religion through corporations...

363. Id. at 12 .

364. Id. at 11 .

365. Id.

366. Id. at 10-12 (emphasis added). 
There is no separating the Hahns' faith from their business or its actions. The members of the Hahn family, as Mennonite Christians, practice their faith in everything they do, including the running of their business. ${ }^{367}$

The scribes for the Hobby Lobby and Conestoga briefs spilled substantial ink in their statements of facts to hammer-home this theme. They did so by giving us a vivid picture of the individuals running the corporations. ${ }^{368}$ This conjured up images of a simple family who, like many American families, likely went to church together and sat around the table for Sunday dinner. The briefs also made clear that for these individuals, providing access to the abortifacients in question made them complicit in what they truly believed was a $\sin .{ }^{369}$

Justice Alito authored the majority opinion. ${ }^{370}$ In the third paragraph, the opinion immediately embraced the theme that paying for insurance coverage that included abortifacients made the individuals running the corporation complicit in $\sin .^{371}$ The majority also emphatically announced that this constituted a substantial and undue burden imposed by the government, more particularly, the U.S. Department of Health and Human Services ("HHS"). ${ }^{372}$ In other words, this certainly was a "straight-forward" RFRA case, just as Hobby Lobby argued in its "hello." As Justice Alito plainly stated:

If the owners comply with the HHS mandate, they believe they will be facilitating abortions, and if they do not comply, they will pay a very heavy price - as much as $\$ 1.3$ million per day, or about $\$ 475$ million per year, in the case of one of the companies. If these consequences do not amount to a substantial burden, it is hard to see what would. ${ }^{373}$

In the fifth and sixth paragraphs, Justice Alito focused on the same "straightforward" analysis as to why the RFRA had been violated that Hobby Lobby set forth in its "hello." 374 The government gave an exemption to others, so why couldn't the government give an exemption to Hobby Lobby? As Justice Alito explained:

In fact, HHS has already devised and implemented a system that seeks to respect the religious liberty of religious nonprofit corporations while ensuring that the employees of these entities have precisely the same access to all FDA-approved contraceptives as employees of companies whose owners have no religious objections to providing such coverage ... Although HHS has made this system available to religious nonprofits

367. Brief for Petitioners at 2-3, Burwell v. Hobby Lobby Stores, Inc., 134 S. Ct. 2751 (2014) (No. 13-356), 2014 WL 173487 (emphasis added) [hereinafter Petitioners' Brief, Hobby Lobby].

368. See, e.g., id. at 43.

369. See e.g., id. at 29.

370. Burwell v. Hobby Lobby Stores, Inc., 134 S. Ct. 2751 (2014).

371. Id. at 2759.

372. Id.

373. Id. (emphasis added).

374. Id. at 2759-60. 
that have religious objections to the contraceptive mandate, HHS has provided no reason why the same system cannot be made available when the owners of for-profit corporations have similar religious objections. We therefore conclude that this system constitutes an alternative that achieves all of the Government's aims while providing greater respect for religious liberty. ${ }^{375}$

The briefing brilliantly continued to capitalize on the well-established technique of humanizing a corporation. Although Hobby Lobby employed close to 14,000 employees, which puts it on par with other major corporations such as General Mills, Goldman Sachs, Four Season Hotels, CarMax, and Men's Wearhouse, ${ }^{376}$ the briefing essentially characterized the company as a homespun mom-and-pop family business. ${ }^{377}$ Similarly, Conestoga had 950 employees, still quite a large number. ${ }^{378}$ But, like Hobby Lobby, Conestoga's brief described it as a small-time company that the father launched in the family garage. ${ }^{379}$ For both cases, the Supreme Court identified family members as having the top positions in the company. ${ }^{380}$ Paragraph upon paragraph touched upon concrete acts demonstrating the sincerity of the family members' religious beliefs. ${ }^{381}$ In pertinent part, the Hobby Lobby brief provided:

Respondents are David and Barbara Green; their children, Steve Green, Mart Green, and Darsee Lett; and their family businesses, Hobby Lobby Stores, an arts-and-crafts chain, and Mardel, a chain of Christian bookstores.

Founded in 1970 by David Green, Hobby Lobby has grown from a single arts-and-crafts store in Oklahom a City into a nationwide chain with over 500 stores and more than 13,000 full-time employees. In 1981, Mart Green founded Mardel, an affiliated chain of Christian bookstores, which now has thirty-five stores and about 400 full-time employees. Hobby Lobby and Mardel remain closely held family businesses, organized as general corporations under Oklahoma law, and exclusively controlled by the Greens. David Green is Hobby Lobby's CEO, his son Steve is President, his daughter Darsee is Vice President, and his son Mart is

375. Id. at 2759 (emphasis added).

376. 100 Best Companies to Work For, FORTUNE, http://archive.fortune.com/magazines/ fortune/bestcompanies/2011/size/ [http://perma.cc/E8YZ-CSER] (last visited October 12, 2015) (noting the precise number of employees listed for each of these companies is as follows: Goldman Sachs $(13,154)$, General Mills $(16,803)$, Four Season Hotels $(11,729)$, CarMax $(13,436)$, and Men's Wearhouse $(14,548))$.

377. Respondents' Brief, Hobby Lobby, supra note 361, at 7-10.

378. Hobby Lobby, 134 S. Ct. at 2764.

379. Id.

380. Respondents' Brief, Hobby Lobby, supra note 361, at 8; Petitioners' Brief, Hobby Lobby, supra note 367 , at $4-5$.

381. Respondents' Brief, Hobby Lobby, supra note 361, at 7-9. 
Vice CEO of Hobby Lobby and CEO of Mardel. For federal tax purposes, Hobby Lobby is a subchapter-S corporation.

"The Greens have organized their businesses with express religious principles in mind." Hobby Lobby's official statement of purpose commits the company to "[h] onoring the Lord in all we do by operating the company in a manner consistent with Biblical principles" ... The Greens each signed a Statement of Faith and a Trustee Commitment obligating them to conduct the businesses according to their religious beliefs, to "honor God with all that has been entrusted" to them, and to "use the Green family assets to create, support, and leverage the efforts of Christian ministries."

"[T]he Greens allow their faith to guide business decisions for both companies." All Hobby Lobby stores close on Sundays, at a cost of millions per year, to allow employees a day of rest. Each Christmas and Easter, Hobby Lobby buys hundreds of full-page newspaper ads inviting people to "know Jesus as Lord and Savior." [] Store music features Christian songs. Employees have cost-free access to chaplains, spiritual counseling, and religiously-themed financial courses. And company profits provide millions of dollars every year to ministries.

Respondents also refrain from business activities forbidden by their religious beliefs. For example, to avoid promoting alcohol, Hobby Lobby does not sell shot glasses. Hobby Lobby once declined a liquor store's offer to take over one of its building leases, costing it hundreds of thousands of dollars a year. Similarly, Hobby Lobby does not allow its trucks to "back-haul" beer and so loses substantial profits by refusing offers from distributors.

In the same way, Respondents' faith affects the insurance offered in Hobby Lobby's self-funded health plan. Respondents believe that human beings deserve protection from the moment of conception, and that providing insurance coverage for items that risk killing an embryo makes them complicit in abortion. ${ }^{382}$

These facts did indeed demonstrate the sincerity of the family members' beliefs. In other words, they practiced what they preached and they had done so since long before they were ever required to provide insurance coverage that included access to abortifacients. Yet, technically, these facts were irrelevant to the legal issues before the Supreme Court because the government-perhaps wisely-did not dispute these highly emotive facts. To be clear, as Justice Alito expressly stated in the majority opinion: "The companies in the cases before us are closely held corporations, each owned and controlled by members of a single

382. Id. at 7-9 (emphasis added) (citations omitted). 
family, and no one has disputed the sincerity of their religious beliefs." ${ }^{383}$

Given the technical irrelevance of the background facts, that was all that needed to be said. The sincerity element necessary to establish a violation of the RFRA was met. ${ }^{384}$ But that hardly satisfied the need for an emotional appeal. Justice Alito carefully laid out the emotive facts for both of the two corporations discussed in the opinion. ${ }^{385}$ In both style and substance, this depiction would track the facts set forth in the briefs. In pertinent part, this is how Justice Alito described the family owners of Hobby Lobby:

David and Barbara Green and their three children are Christians who own and operate two family businesses. Forty-five years ago, David Green started an arts-and-crafts store that has grown into a nationwide chain called Hobby Lobby. There are now 500 Hobby Lobby stores, and the company has more than 13,000 employees. Hobby Lobby is organized as a for-profit corporation under Oklahoma law.

One of David's sons started an affiliated business, Mardel, which operates 35 Christian bookstores and employs close to 400 people. Mardel is also organized as a for-profit corporation under Oklahoma law.

Though these two businesses have expanded over the years, they remain closely held, and David, Barbara, and their children retain exclusive control of both companies. David serves as the CEO of Hobby Lobby, and his three children serve as the president, vice president, and vice CEO.

Hobby Lobby's statement of purpose commits the Greens to "[h] onoring the Lord in all [they] do by operating the company in a manner consistent with Biblical principles." Each family member has signed a pledge to run the businesses in accordance with the family's religious beliefs and to use the family assets to support Christian ministries. In accordance with those commitments, Hobby Lobby and Mardel stores close on Sundays, even though the Greens calculate that they lose millions in sales annually by doing so. The businesses refuse to engage in profitable transactions that facilitate or promote alcohol use; they contribute profits to Christian missionaries and ministries; and they buy hundreds of full-page newspaper ads inviting people to "know Jesus as Lord and Savior."

Like the [family in Conestoga], the Greens believe that life begins at conception and that it would violate their religion to facilitate access to

383. Hobby Lobby, 134 S. Ct. at 2774.

384. Id.

385. Id. at $2765-66$. 
contraceptive drugs or devices that operate after that point. ${ }^{386}$

There were also striking similarities between Conestoga's statement of facts and the majority opinion. The Supreme Court noted that Norman Hahn started the business in his "garage" and that the "Hahns exercise sole ownership of the closely held business; they control its board of directors and hold all of its voting shares." 387 The majority opinion then went on to largely quote and cite directly to the Conestoga brief. ${ }^{388}$

Another tried-and-true technique the Hobby Lobby attorneys used was suggesting that the Supreme Court could rule very narrowly, meaning the Supreme Court could provide relief for only their client. This works nicely with the technique of truly focusing on the lives of the human beings that controlled the corporation. How could the justices deny a religious exemption for the particular litigants before the Court, especially given that their religious convictions long pre-dated the ACA? This added credibility (ethos) to their claim and set them apart from those who might ride on the RFRA bandwagon by falsely claiming religious beliefs justify exemption from the requirements of the ACA or from other newly announced rules of law.

Again, although we may never know whether a particular brief-or its "hello"- truly swayed a particular judge in any given case, it seems very clear that the Supreme Court does bite on well-written emotional appeals. This especially is so when the emotional appeals make the decision more palatable. Given this reality, it would seem foolish for a practitioner not to provide the Court with the tools and building blocks to enunciate an emotional appeal in the Court opinion. Put simply, the ink is not wasted.

If humanizing a corporation with 14,000 employees-or in AT\&T's case, hundreds of thousands of employees - is a tall order, then making an executioner the "good guy" is even taller. ${ }^{389}$ Yet that was achieved in the prevailing brief in Glossip v Gross.

\section{E. Glossip v. Gross: Death Penalty/Drug Protocol}

If there is one category of cases that indisputably triggers emotions, it is death penalty cases - and rightfully so. A person's life is at stake, and-when viewed from the other side - a person's life has been taken, sometimes many. Justice Thomas' passionate concurrence championed this view while also displaying his frustration with the liberal-leaning justices. ${ }^{390} \mathrm{He}$ used multiple paragraphs depicting graphic and gruesome details of murders committed by convicted prisoners that have been spared execution solely by order of the Supreme

386. Id. (emphasis added) (citations omitted).

387. Id. at 2764 .

388. See e.g., id. at 2779-80.

389. AT\&T Company Statistics, Stat. Brain Res. InSt. (Aug. 14, 2015), http://www. statisticbrain.com/att-company-statistics/ [http://perma.cc/ZS6Z-84R6] (estimating AT\&T has 266,590 global employees).

390. Glossip v. Gross, 135 S. Ct. 2726, 2750-55 (2015) (Thomas, J., concurring). 
Court. ${ }^{391}$ By contrast, Justice Breyer's equally passionate dissent set forth numerous reasons why the very constitutionality of the death penalty should be revisited. ${ }^{392}$ This included multiple paragraphs identifying specific individuals who either have been-or almost were-executed and then later were proven innocent. ${ }^{393}$ So polarized and entrenched are the members of the Supreme Court on this issue that Justice Scalia began his concurrence with the simple words: "Welcome to Groundhog Day." 394

At issue in Glossip was whether a three-drug protocol utilized by Oklahoma constituted "cruel and unusual punishment," thereby violating the Eight Amendment. ${ }^{395}$ More particularly, the dispute revolved around the paralytic drug, midazolam, which was substituted for another paralytic drug, pavulim, which had previously been approved for use in executions in Baze v. Rees. ${ }^{396}$ The petitioners contended midazolam was not effective in rendering a prisoner insensitive to pain. ${ }^{397}$

Both briefs powerfully presented their respective "hellos." Perhaps the most emotionally compelling portion of the petitioners" "hello" was the very first paragraph, which not only vividly described the pain a prisoner might suffer, but also introduced the concept that use of the paralytic drug was more successful at masking the pain to viewers than it was at eliminating that pain for prisoner facing execution. ${ }^{398}$ As set forth in the petitioners' "hello":

Oklahoma intends to execute petitioners by injecting them with large amounts of a paralytic drug and potassium chloride. The paralytic drug produces a chemical entombment, paralyzing and eventually suffocating the person. Potassium chloride feels like liquid fire as it courses through the veins; it eventually stops the heart. Throughout this process, the paralytic drug ensures that observers see no evidence of suffering, because the prisoner will be completely paralyzed.

It is constitutionally intolerable to use these drugs to execute any prisoner still capable of sensing pain. These drugs cause not merely death, but also agonizing pain and suffering. Such a method of execution violates the Eighth Amendment's prohibition against cruel and unusual punishment. The Framers placed off limits such means of execution as burning a prisoner. From the perspective of causing intolerable pain and suffering, injecting a prisoner with liquid fire is just as unconstitutional

391. Id.

392. Id. at 2756-77 (Breyer, J., dissenting).

393. Id. at $2756-58$.

394. Id. at 2746 (Scalia, J., concurring).

395. Id. at 2735.

396. Id. at 2731, 2733 (citing Baze v. Rees, 553 U.S. 35 (2008)).

397. Id. at 2731.

398. Brief for Petitioners at 2, Glossip v. Gross, 135 S. Ct. 2726 (2015) (No. 14-7955), 2015

WL 1045426 [Petitioners' Brief, Glossip]. 
as lighting him afire. ${ }^{399}$

This suggested that the use of the paralytic drug does more to quell the stomachs of onlookers than ease the pain of an execution; it utilized the principle that if you can get someone to look at something differently, this might just change their mind. Characterizing the drug as akin to "liquid fire" was also powerful as it set up the ending comparison with burning a prisoner at the stake, which the Court already deemed "cruel and unusual" punishment. ${ }^{400}$

Yet Oklahoma had a trump card and Oklahoma played it front-and-center in its "hello." Left unsaid in the petitioners" "hello" was why Oklahoma did not use a more effective and less painful drug, such as the drugs the Supreme Court already approved. Oklahoma had the answer. ${ }^{401}$ Rather than being the heartless executioner, Oklahoma was the victim. ${ }^{402}$ It long sought to find the most humane method of lethal injection - and succeeded — only to be thwarted by death-penalty opponents who pressured drug companies to cut off supply. ${ }^{403}$ In Oklahoma's words:

It was Oklahoma that in 1977 tasked its medical experts with developing a more humane alternative to electrocution. The resulting three-drug lethal injection protocol was adopted by every jurisdiction in the United States. When death penalty opponents' attacks on the effectiveness of the first drug, sodium thiopental, proved unsuccessful, they turned to cutting off supplies to the States. Oklahoma led the switch to pentobarbital, which too was adopted by virtually every jurisdiction. Pentobarbital acquired a well-established record of reliability and effectiveness, despite the same accusations that it could not reliably lead to painless executions.

And now, after death penalty opponents have pressured manufacturers of pentobarbital to cut off supplies to the States, Oklahoma again has found itself thrust to the forefront of the search for an acceptable-and available-alternative that will allow it to carry out the sovereign duty assigned to it by the people of Oklahoma. As the district court found, Oklahoma has reasonably determined that alternative to be a drug called midazolam ...

Worse still, feigning ignorance of the very drug shortage that their supporters helped create, Petitioners allege that Oklahoma turned to midazolam not in a good faith effort to find the best available alternative drug but out of callous "expediency." All the while, Petitioners steadfastly refuse to identify a single better option available to

399. Id. (emphasis added).

400. Id. at 29 .

401. Brief for Respondents at 1-3, Glossip v. Gross, 135 S. Ct. 2726 (2015) (No. 14-7955), 2015 WL 1619433 [Respondents’ Brief, Glossip].

402. Id.

403. Id 
Oklahoma. This fact alone demonstrates that this case, under the guise of a narrow attack on a single method of execution out of many, is a fullthroated attack on the ability of the sovereign States to carry out the death sentences issued by their citizens. ${ }^{404}$

Of course, as Justice Sotomayor pointed out in her dissent, the fact that a drug is unavailable is irrelevant. ${ }^{405}$ The legal issue turned on whether a proposed drug constituted "cruel and unusual" punishment. ${ }^{406}$ At oral argument, Justice Alito brought up what would be referred to in media reports as the "elephant in the room," namely, the unavailability of the preferred drug and the reasons why. ${ }^{407}$ Yet as Justice Sotomayor pointed out in her dissent, there was no evidence that the petitioners themselves had any role in that. ${ }^{408}$ Still, would all of this make it into the Supreme Court opinion? Of course.

Justice Alito penned the majority opinion. ${ }^{409}$ It began with a long and emotive history of the death penalty and its justifications. ${ }^{410}$ Then came that elephant. Justice Alito spent four long paragraphs sounding the emotional theme set forth in Oklahoma's "hello." 411 Use of midazolam to execute the petitioners was necessary because of the conduct of death-penalty opponents. ${ }^{412}$ As Justice Alito stated in detail:

Baze cleared any legal obstacle to use of the most common three-drug protocol that had enabled States to carry out the death penalty in a quick and painless fashion. But a practical obstacle soon emerged, as antideath-penalty advocates pressured pharmaceutical companies to refuse to supply the drugs used to carry out death sentences. The sole American manufacturer of sodium thiopental, the first drug used in the standard three-drug protocol, was persuaded to cease production of the drug. After suspending domestic production in 2009 , the company planned to resume production in Italy. Activists then pressured both the company and the Italian Government to stop the sale of sodium thiopental for use in lethal injections in this country. That effort proved successful, and in January 2011 , the company announced that it would exit the sodium thiopental market entirely.

404. Id. at 2-3 (emphasis added).

405. Glossip v. Gross, 135 S. Ct. 2726, 2794 (2015) (Sotomayor, J., dissenting).

406. Id. at 2792-95.

407. Mark Wilson, Glossip v. Gross Oral Arguments: How Painful Is It?, FindLAw (April 29, 2015, 11:55 AM), http://blogs.findlaw.com/supreme_court/2015/04/glossip-v-gross-oralarguments-how-painful-is-painful.html [http://perma.cc/HM4T-B7UT]; see also Transcript of Oral Argument at 14-15, Glossip v. Gross, 135 S. Ct. 2726 (2015) (No. 14-7955).

408. Glossip, 135 S. Ct. at 2796 (Sotomayor, J., dissenting).

409. Id. at 2731 (majority opinion).

410. Id. at 2731-33.

411. Id. at $2733-34$.

412. Id. 
After other efforts to procure sodium thiopental proved unsuccessful, States sought an alternative, and they eventually replaced sodium thiopental with pentobarbital, another barbiturate. In December 2010, Oklahoma became the first State to execute an inmate using pentobarbital. That execution occurred without incident, and States gradually shifted to pentobarbital as their supplies of sodium thiopental ran out. It is reported that pentobarbital was used in all of the 43 executions carried out in 2012. Petitioners concede that pentobarbital, like sodium thiopental, can "reliably induce and maintain a comalike state that renders a person insensate to pain" caused by administration of the second and third drugs in the protocol. And courts across the country have held that the use of pentobarbital in executions does not violate the Eighth Amendment.

Before long, however, pentobarbital also became unavailable. Antideath-penalty advocates lobbied the Danish manufacturer of the drug to stop selling it for use in executions. That manufacturer opposed the death penalty and took steps to block the shipment of pentobarbital for use in executions in the United States. Oklahoma eventually became unable to acquire the drug through any means. The District Court below found that both sodium thiopental and pentobarbital are now unavailable to Oklahoma.

Unable to acquire either sodium thiopental or pentobarbital, some States have turned to midazolam, a sedative in the benzodiazepine family of drugs. In October 2013, Florida became the first State to substitute midazolam for pentobarbital as part of a three-drug lethal injection protocol. To date, Florida has conducted 11 executions using that protocol, which calls for midazolam followed by a paralytic agent and potassium chloride. In 2014, Oklahoma also substituted midazolam for pentobarbital as part of its three-drug protocol. ${ }^{413}$

As noted above, often there are two competing manners of viewing the legal issue. Here, if the lens chosen is one that focuses on the humaneness of the state in choosing a method of execution, then the availability or unavailability of a preferred drug is relevant. By contrast, if the focus is strictly on whether use of a particular drug constitutes "cruel and unusual" punishment, the unavailability of a preferred drug does not matter. Either use of the drug is "cruel and unusual" or it is not. Still, every case can-and perhaps should - be justified both legally and morally. The emotional appeal in Oklahoma's brief certainly supplied that for proponents of the death penalty.

The Glossip "hello" again teaches practitioners that they must always strive to win the reader over both emotionally and intellectually and that definitely includes grabbing the reader at "hello."

413. Id. (emphasis added). 


\section{LESSONS LEARNED: TIPS FOR THE APPELlate AND TRIAL COURT Practitioner on How To Draft Powerful, Persuasive, AND MEMORABLE "HeLlos"}

Gotcha! The "hellos" and emotional appeals discussed above demonstrate the powerful impact a brief may have on a close judicial decision. Even a skeptical reader must admit pathos certainly has a place in Supreme Court opinions and that pathos comes from one primary source: the briefs. Perhaps you are even wondering whether maybe, just maybe emotions can sometimes sway a judge? The passionate opinions discussed above certainly suggest that the Supreme Court justices are emotionally invested in the cases they decide and maybe that's a good thing. As Friedman suggested, there is a "tacit deal" to never stray too far from what the American public believes is fair. ${ }^{414}$ But before we all gather around a fire pit and start singing Kumbaya, let's stick to the brass tacks.

The thoughts set forth in this Article apply at the trial court level as well as the appellate level. In fact, conventional wisdom suggests that trial courts are more open to emotional appeals than appellate panels. If asked, most judges will say they want to do justice in their courtroom. For example, many judges will go beyond the call of duty to assist an unrepresented civil litigant who is up against an army of corporate attorneys. But sensibilities can lean the other way. Judges also get annoyed at lawsuits that arguably benefit the lawyers more than the litigants. In any event, a judge certainly does not want to be the conduit for injustice. At their core, judges-like us - want a result that is fair. It is your job as a practitioner to make your judge see why a ruling in your client's favor accomplishes that.

Many articles discuss the importance of "story" or "narrative" and suggest that legal writers try and work their facts into one of the conventional or stock story-telling models: David versus Goliath; good-guy versus bad-guy; hero versus villain. Although that is important, the point of this Article is that you really do have to grab the reader from the get-go. In Hollywood, a scriptwriter would never wait until page thirty-seven to do that. The reader needs to be emotionally and intellectually engaged in the opening scene. The same reasoning applies to legal briefs. You need to find a way to convey your theme-like David versus Goliath-in one or two sentences at the very beginning of your "hello." You also need to weave that theme through the entirety of your brief. Put differently, once you grab the reader, do not let go.

Another important point is that societal values may change on a dime. A hook that may have worked five years ago-or even five minutes ago-may not work now. The court of public approval is quickly moving toward a model of snap judgments. With real-time reactions streaming in through Twitter and other forms of social media, individuals are quick to either champion or condemn. Millions more jump on the bandwagon, often with little or no knowledge of the actual facts. Even those who do not follow social media are still exposed to this

414. FRIEDMAN, supra note 104, at 4. 
phenomenon through reports on traditional Internet sources such as Yahoo! or MSN

The Internet changed the way we read and think. We process much more information than ever before and do so at a much faster rate. A day's worth of news may be scrolled through in a minute flat on a smartphone. Those generating content capture the essence of a story in four or five words printed below a visual image. Such "headlines" are not just limited to major news, but also small town news. Everyday people become heroes - or villains - for actions that decades past never would have attracted a national spotlight. Also long gone are the days when judicial opinions were only read by those in the legal profession. Reported cases can be pulled up by the general public with the click of a mouse or even a voicecommand. All of this has to have an effect on the manner in which judges-and their clerks - read briefs. Now more than ever, an effective brief writer has to win the reader over both in the heart and in the mind and do so instantly.

Where all of this really comes into play is in "open cases." As noted above, briefing in a hotly contested matter may reveal that both sides could be right (or wrong) under existing precedent. Arguably, most judicial decisions fall under this umbrella. Again, why is it surprising that pathos might tip the scales in this circumstance? There also is a practical benefit. Even at the trial level, providing your judge with a powerful emotional story line gives your judge the tools to craft a compelling opinion. It also lays the record for a powerful showing on appeal. Winning both emotionally and intellectually gives a judge greater confidence that a ruling in your client's favor will not be reversed.

So how do you craft a powerful "hello" that bowls over your judge both in the heart and in the mind? Below are ten tips for practitioners that are gleaned from the analysis of the "hellos" in this Article. It is not intended to be an allinclusive list, but it is a start.

\section{TEN TIPS FOR PRACTITIONERS}

\section{A. Get to the Point and Quick}

If there is one lesson to learn from this Article, it is that you must never bury your emotional hooks deep in your brief. Your emotional appeal must be set forth in your "hello," ideally in the first sentence. The Adoptive Couple "hello" did this and created that jaw-dropping image of a dead-beat dad that would be difficult for many to get past. ${ }^{415}$ Similarly, the very first sentence in the Concepcion "hello" made clear that a trial court judge found the arbitration agreement the most "fair and consumer-friendly" agreement that judge had ever seen. ${ }^{416}$ In fact, all of the prevailing briefs wasted little time before hitting the pathos button.

\section{B. Identify the Elephant in the Room}

This author likes to call this the "WRGO" of a case, an acronym for "what's

415. Petitioners' Brief, Adoptive Couple, supra note 286, at 7.

416. Petitioners' Brief, Concepcion, supra note 327, at 1. 
really going on." This cuts to the core of why a judge should rule in your favor. The quintessential example is the Glossip "hello" which flatly laid out the reason why Oklahoma could not obtain an approved drug for its executions: deathpenalty opponents pushed manufactures to cut off supply. ${ }^{417}$ This technique also was effectively used in Concepcion ${ }^{418}$ Do we want more frivolous class action lawsuits, or less? Of course, your WRGO might be vastly different from your opponent's WRGO. That does not matter. Take control and tell the story from your client's perspective.

\section{Let the Facts Speak for Themselves}

Facts decide cases. The key is to present facts in a manner that forces an emotional reaction from your reader. No one wants to listen to a biased attorney ramble about what is fair and just. Instead, let the facts speak for themselves. The winner here? Again, the "hello" in Adoptive Couple is hard to beat. But runnersup certainly include the brief writers in Windsor. This "hello" presented concrete, seemingly objective facts about Edie and Thea that allowed the reader to see and feel the discrimination these two women felt throughout their forty-four-year relationship. ${ }^{419}$ A corollary of this rule is not to whine or "soap-box." That is nowhere near as powerful as letting the reader come to his or her own conclusion as to why justice demands a ruling in your client's favor. There is an adage that is taught in first-year writing classes: the judge does not care what you think; the judge wants to know what the facts and the law state. ${ }^{420}$

\section{Use Vivid Words and Images}

Vibrant words conjure up vibrant images. Such images are hard to dismiss, especially when they trigger an emotional response. The first sentence of the Obergefell "hello" referenced the need to "protect[] families throughout life, from cradle to grave." 221 Ohio "erase [d]" a family's legal relationship and rendered spouses "legal strangers." 422 Although it was not the prevailing brief, kudos must be given to the attorneys drafting the brief for the Glossip petitioners. They vividly described the paralytic drug at issue as feeling like "liquid fire as it courses through the veins. ${ }^{" 423}$ This set up that powerful last line that argued "injecting a prisoner with liquid fire is just as unconstitutional as lighting him

417. Glossip, 135 S. Ct. at 2733-34.

418. See e.g., Petitioners' Brief, Concepcion, supra note 327, at 1.

419. Respondents' Brief, Windsor, supra note 131, at 1-3.

420. Anderson, supra note 27, at 12 (quoting K. N. Llewellyn, The Modern Approach to Counselling and Advocacy-Especially in Commercial Transactions, 46 Colum. L. REv. 167, 183 (1946) ("The court is interested not in listening to a lawyer rant, but in seeing, or discovering, from and in the facts, where sense and justice lie.")).

421. Petitioners' Brief, Obergefell, supra note 235, at 3.

422. Id.

423. Petitioners' Brief, Glossip, supra note 398, at 1. 
afire. ${ }^{424}$

\section{E. Tether Your Emotional Hook to a Concrete Legal Argument}

It is never enough to just make a judge feel bad for your client. You must win over the judge intellectually. Put differently, make clear from the get-go that there is a sound legal basis to rule in your favor. The Hobby Lobby "hello" opened with a common-sense rationale for providing the corporation with an exemption under the RFRA: the government already handed out such exemptions for non-profit corporations. This provided a nice segue to championing the rights of the individuals running the corporation. Why shouldn't they get the same exemption? This especially was so given they believed that they would be complicit in sin if they provided health-care coverage that included access to abortifacients. The more concrete the legal argument, the more inviting the emotional hook.

\section{F. Reframe an Issue So That It Forces the Reader to Take a Fresh Look}

When the law truly appears to be against you, the best course may be to reframe the issue completely. For example, in Hollingsworth, California offered civil unions that provided same-sex couples with the exact same rights as heterosexual "married" couples. ${ }^{425}$ In other words, there was not a single right or benefit that California law denied same-sex couples. The only difference was the name: "civil union" versus "marriage." What difference could that possibly make? When handed lemons, the Hollingsworth brief writers made lemonade. It was all about the name. Use of two different labels demeaned and stigmatized same-sex couples and their children ${ }^{426}$ This set up the sound legal argument that under an "evolving" interpretation of the federal constitution, same-sex couples could not be denied the fundamental right to marry. Like their heterosexual counterparts, these couples-and their children-deserved legal recognition.

\section{G. Stay in Touch with Reality/Know Your Judge}

As noted above, public sentiment may turn on a dime. Stay abreast of swings in public opinion and try and focus on why such changes may be occurring. Doing so will ensure that your emotional appeals fall on receptive ears. Along that same line, be cognizant of the mindset of your judicial decision-maker(s). At the Supreme Court level, practitioners might target a specific justice. That certainly was seen in Obergefell's "hello" that mirrored Justice Kennedy's eloquent focus in Windsor for "dignity" and the need to protect the children of same-sex couples. ${ }^{427}$ The same reasoning applies at the trial court level. What emotional and legal arguments could swing your judge your way?

424. Id. at 2 .

425. Hollingsworth v. Perry, 133 S. Ct. 2652, 2659 (2013).

426. Respondents' Brief, Hollingsworth, supra note 131, at 1.

427. Petitioners' Brief, Obergefell, supra note 235, at 1-2. 


\section{H. Insulate from Attack}

Coming up with a powerful "hello" that instantly emotionally grabs your reader is fantastic. But is it impervious to attack? Can your opponent swoop in and burst a gaping hole in your carefully crafted "hello"? As seen in Glossip, Oklahoma did just that. Although the petitioners' "hello" certainly was powerful, the petitioners left out one key emotionally-driven fact: death-penalty opponents thwarted Oklahoma's efforts to secure suitable paralytic drugs. ${ }^{428}$ This allowed Oklahoma to cast the petitioners as the villain implicitly, even though there was not even a suggestion that any of the petitioners themselves played any role in the lack of supply. When drafting your "hello," never set yourself up for an easy take-down.

\section{Give as Little Airtime to Your Opponent as Possible}

Remember, it's your "hello," not theirs. Many responding "hellos" come across as defensive. There occasionally are times when the best offense is a good defense, but that typically is only when your opponent truly has gotten the law or facts wrong, or where they have failed to address a key fact, like that "elephant in the room" in Glossip. ${ }^{429}$ Instead, tell your client's story and explain why your client should win-both emotionally and intellectually. The prevailing Glossip "hello" actually did both. In addition to explaining immediately why Oklahoma could not utilize the drug protocol approved in Baze, the "hello" portrayed Oklahoma as having long led the efforts to develop a "more humane alternative" to electrocution. ${ }^{430}$ In other words, Oklahoma was not just not the bad guy (defensive argument); Oklahoma was the benevolent victim (offensive argument).

\section{J. HAMMER-HOME, HAMMER-HOME, HAMMER-HOME}

As noted above, the best emotional hooks are organic and arise from the facts of each case. They also have some relation to the legal issue-even if that relation is technically irrelevant - that enables a writer to weave these emotional hooks throughout the brief. As discussed above, the top brief writers did that again and again. In AT\&T's fifty-seven-page brief there would be forty-one hammer-homes of the perceived fairness of the arbitration agreement by the trial court and the Ninth Circuit. That was in addition to a four-page bullet-point list of the consumer-friendly provisions. ${ }^{431}$ Similarly, in the fifty-seven-page brief filed by the petitioners in Adoptive Couple, there were thirty-nine hammer-homes of their dead-beat dad versus loving couple theme. ${ }^{432}$ It may seem redundant, but it works.

428. Respondents' Brief, Glossip, supra note 401, at 1-3.

429. Id.

430. Id. at 2 .

431. Petitioners' Brief, Concepcion, supra note 327, at 5-8.

432. See generally Petitioners' Brief, Adoptive Couple, supra note 286. 


\section{CONCLUSION}

Bottom line? Judges are human beings. They put on their robes one sleeve at a time. This includes our appellate justices and even the revered nine that take the bench at the Supreme Court. As recognized by legal realists for over a century, it is impossible for judges to truly check emotions at the door. Nor should they. Judges interpret the Constitution based upon "evolving" societal norms. Judges exercise discretion in weighing facts and reconciling competing policy arguments. Judges make decisions that change lives forever. Pathos has been a critical component of debate long before Aristotle graced this Earth and will continue to be long after all of us have passed. Judicial opinions predominantly feature pathos. If you aspire to count yourself amongst the top legal scribes, pathos better be in your "hello." 